\title{
Phytoplankton biomass and size structure across trophic gradients in the southern California Current and adjacent ocean ecosystems
}

\author{
Andrew G. Taylor, Michael R. Landry* \\ Scripps Institution of Oceanography, University of California, San Diego, La Jolla 92093 California, USA
}

ABSTRACT: We used a combination of epifluorescence microscopy and flow cytometry to investigate variability of phytoplankton biomass and size structure with ocean richness, measured as autotrophic carbon (AC) or chlorophyll a (chl a). Samples were collected from mixed layers of 4 North Pacific ecosystems: the California Current (CCE), Equatorial Pacific, Costa Rica Dome, and subtropical gyre (station ALOHA). Both nano- $(2-20 \mu \mathrm{m})$ and microphytoplankton $(20-$ $200 \mu \mathrm{m})$ increased biomass as power functions with increasing richness, with a sharper slope leading to microphytoplankton dominance at high biomass. The AC:chl a ratio $(\mu \mathrm{g}: \mu \mathrm{g})$ was also well fit by a power function, varying from $\sim 170$ to 20 over the range of $<0.06$ to $>11.7 \mu \mathrm{g} \mathrm{chl} \mathrm{a} \mathrm{l}^{-1}$. Prochlorococcus and diatoms were major biomass contributors at poorer and richer extremes, respectively, but mixed flagellates (prymnesiophytes, dinoflagellates, others) comprised a surprisingly consistent half of $\mathrm{AC}$ over the richness range. While pico- $(<2 \mu \mathrm{m})$ and nanophytoplankton codominated at low chl $a$, all picophytoplankton (Prochlorococcus, Synechococcus, picoeukaryotes) declined significantly in richer coastal waters. Their decrease was consistent with a previously proposed mechanism linking Prochlorococcus decline to increased productivity and grazing pressure on heterotrophic bacteria, termed here the enhanced microbial loop hypothesis. Generalized additive models further indicated that biotic variables explained more of picophytoplankton variability than abiotic variables in CCE coastal waters. Density-independent grazing may be a strong driver of picophytoplankton selection across trophic gradients, with implications for strategy trade-offs in growth rate and grazing resistance, and for representing mortality in marine ecosystem models.

${ }^{*}$ Corresponding author: mlandry@ucsd.edu

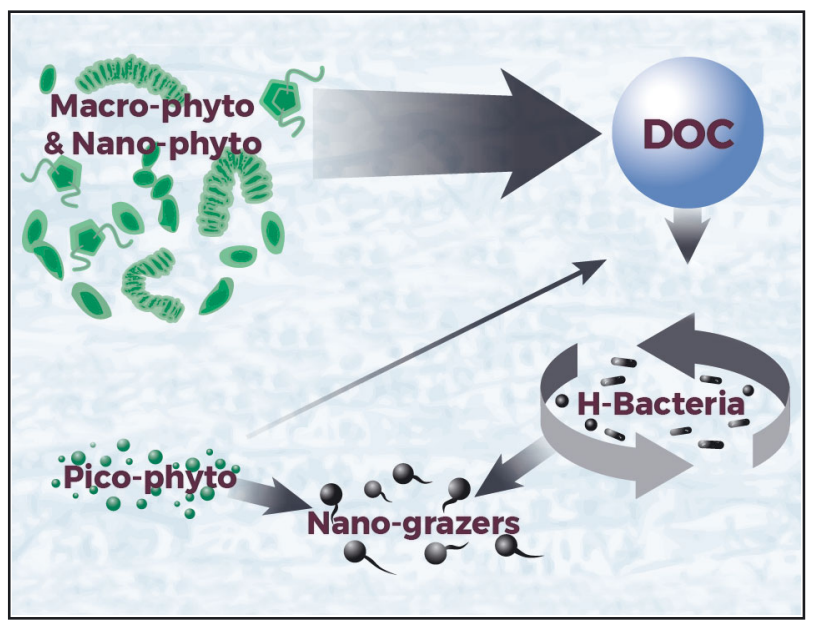

Conceptual depiction of the Enhanced Microbial Loop hypothesis at high chl a

Conceptual depiction: Dennis Mc Thompson

KEY WORDS: Prochlorococcus - Synechococcus · Picoeukaryotes · Ocean richness · Enhanced microbial loop $\cdot$ Grazing

\section{INTRODUCTION}

Many key processes in ocean carbon cycling and biogeochemistry, such as primary production, new production, nutrient and trace element limitation and carbon export from the euphotic zone, are strongly related to the biomass structure and composition of phytoplankton communities (Eppley \& Peterson 1979, Long-

(C) The authors 2018. Open Access under Creative Commons by Attribution Licence. Use, distribution and reproduction are unrestricted. Authors and original publication must be credited. 
hurst 1991, Falkowski et al. 2000, Marañón 2015). In addition, the size structure of phytoplankton communities directly impacts food web length and trophic efficiency, with nutrient-rich regions typically supporting larger phytoplankton and fewer food web steps to higher-level consumers than in nutrient-poor systems (Ryther 1969, Fenchel 1988, Iverson 1990). Because phytoplankton structure is important for understanding and modeling such processes, many attempts have been made to assess phytoplankton community biomass, structure and production based on a few key, often remotely sensed, parameters, such as water temperature and chlorophyll a (Platt 1986, Morel \& Berthon 1989, Behrenfeld et al. 2005, Hirata et al. 2008). These remain somewhat elusive goals because large field data sets of quantitatively measured phytoplankton biomass are relatively sparse in ocean studies.

It is broadly understood that phytoplankton communities are influenced both by physical/chemical (bottom up: temperature, light and macro- and micronutrients) and by biological/trophic (top down: grazing) forcing (Tilman 1977, Tilman et al. 1982, Hecky \& Kilham 1988, Goericke 2002, Calbet \& Landry 2004, Sundt-Hansen et al. 2006, Falkowski \& Oliver 2007), and various hypotheses have emerged to explain how such mechanisms may interact to regulate community composition and biomass. One of these, which we term 'step addition,' envisions the community response to increasing nutrient inventory as creating new niches for larger cells that are added to a stable foundation of smaller cells (Chisholm 1992, Thingstad 1998). According to this view, grazing controls set upper limits on the biomass that can be achieved by smaller competitive dominants for nutrients, and larger taxa are laid sequentially on top as the resource base expands. Smaller size classes are thus predicted to achieve a maximum biomass in relatively low-nutrient systems but remain relatively constant in biomass as richness increases. Alternatively, the 'rising tide' hypothesis of Barber \& Hiscock (2006) predicts that improved nutrient conditions for growth should benefit all phytoplankton size classes. According to this hypothesis, smaller size classes of cells increase steadily in biomass with increasing system richness, even as larger cells increase disproportionately to eventually dominate community biomass.

Although no general hypothesis has been advanced to predict a broad biomass decline of small phytoplankton with increasing system richness, several studies have noted that specific populations like Prochlorococcus (PRO) can be driven to lower concentration by increasing grazing pressure linked to the dynamics of comparably sized heterotrophic bacteria. Kuipers \&
Witte (2000), for instance, observed that grazing mortality on PRO in the chlorophyll maximum of the subtropical North Atlantic was correlated with the loss rates of heterotrophic bacteria and was independent of PRO abundance, growth rate or timing of cell division. These results supported their hypothesis that PRO was taken mainly as a bycatch of small grazers feeding on bacteria and was not separately regulated by density-dependent interactions with its unique suite of consumers. Coupled grazing dynamics of PRO and heterotrophic bacteria, stimulated by increased supply of dissolved organic carbon (DOC) to bacteria from bloom-forming phytoplankton, have also been speculated to explain observed population responses to iron fertilization in the equatorial Pacific (Landry \& Kirchman 2002). More recently, Goericke (2011a) extended this mechanism to explain the observed decrease of PRO across the California Current as a consequence of increased grazing pressure tied to the improved growth environment for heterotrophic bacteria. Such a mechanism, which we call here the 'enhanced microbial loop' hypothesis, might reasonably apply to all phytoplankton in the pico $(<2 \mu \mathrm{m})$ size range which share common predators with bacteria. It thus provides the basis for a third possibility - that small phytoplankton, in general, may decline with increasing system richness.

In the present study, we investigated the variability of phytoplankton community composition, biomass and size structure with increasing system richness, measured as total autotrophic biomass or chlorophyll $a$ (chl a). The data consist of 949 mixed-layer assessments of community biomass and composition by combined digital epifluorescence microscopy and flow cytometry. Samples were collected throughout the euphotic zone from 4 diverse oceanic systems in the central and eastern North Pacific, including coastal upwelling, oligotrophic subtropical and open-ocean high-nitrate, low-chlorophyll a (HNLC) regions. Across these regions, we demonstrate a coherent pattern of size-class variability, with monotonically increasing nano- and microphytoplankton and declining picophytoplankton biomass in richer coastal conditions. We also reveal compositional and structural differences among the 4 investigated regions over the portion of the biomass spectrum where they overlap, and develop generalized additive models to assess the relative contributions of biotic and abiotic variables to explaining variability in picophytoplankton biomass. These results support the idea that production-enhanced increases in heterotrophic bacteria and nanoflagellate grazers of bacteria can lead to a general decline of picophytoplankton in rich coastal systems. 


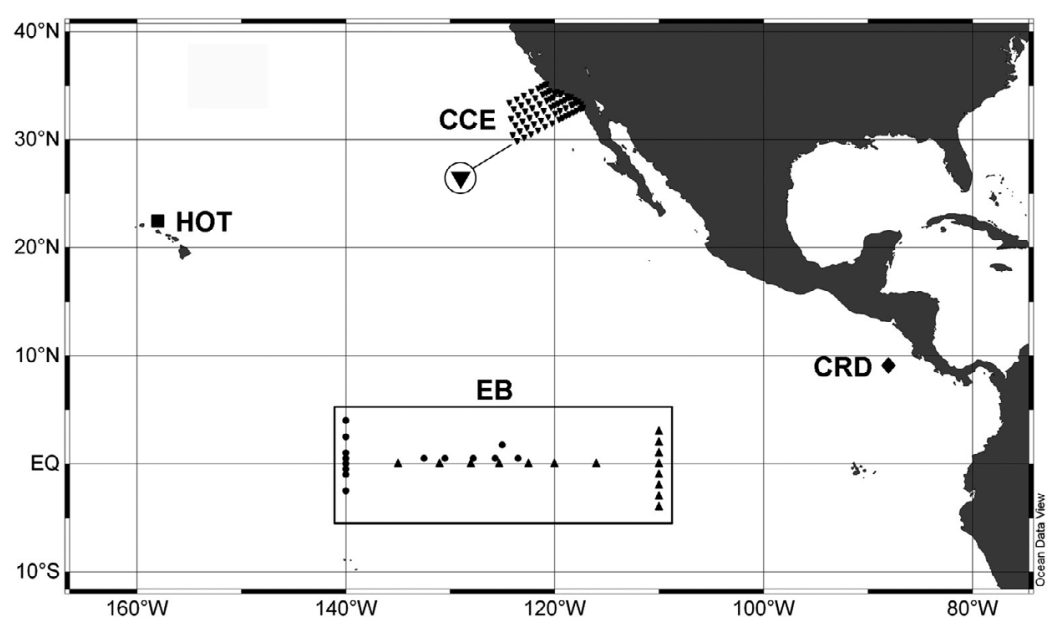

Fig. 1. Areas of sample collection: California Current Ecosystem (CCE), Hawaii Ocean Time-series (HOT), Equatorial Biocomplexity project (EB) and the Costa Rica Dome (CRD). Inverted triangle symbols for the CCE region represent the California Cooperative Oceanic Fisheries Investigations sampling grid

tropical downwelling (HOT), HNLC waters associated with chronic iron limitation (EB) and highly stratified waters overlying a shallow oxygen minimum zone (CRD). CCE data come both from designed experimental process studies over a range of coastal to offshore conditions, as well as from sampling at 10 cardinal stations along lines 80 and 90 of the California Cooperative Oceanic Fisheries Investigations (CalCOFI) during 25 quarterly cruises from November 2004 to October 2010. On all cruises, samples for microscopy, flow cytometry and chl a analyses were collected with CTDrosette bottles taken from 3-8 depths from the surface to the bottom of the euphotic zone $(\sim 0.1 \%$ of incident solar radiation). Here, however, our analysis

\section{MATERIALS AND METHODS}

\section{Study areas and sampling}

Data were collected over a 6 yr period (2004-2010) from 4 areas and research projects in the central to eastern North Pacific Ocean (Fig. 1, Table 1): the California Current Ecosystem Long Term Ecological Research (CCE-LTER) program off southern California (Ohman et al. 2013); the Hawaii Ocean Timeseries (HOT) program at ocean station ALOHA (Karl \& Lukas 1996); the Equatorial Biocomplexity (EB) project in the eastern equatorial Pacific between $110^{\circ}$ and $140^{\circ} \mathrm{W}$ (Nelson \& Landry 2011) and the Flux and Zinc Experiment (Stukel et al. 2013, Landry et al. 2016) in the Costa Rica Dome (CRD). These studies cover a broad range of phytoplankton growth conditions in tropical to temperate marine ecosystems of the Pacific Ocean, including eutrophic coastal upwelling (CCE), oligotrophic open-ocean and sub- is based on samples taken only in the upper $30 \mathrm{~m}$ (nominally the surface mixed layer), so as not to confound depth variability in phytoplankton biomass due to light limitation with spatial variability associated with nutrients and trophic richness.

\section{Analysis of eukaryotic plankton by epifluorescence microscopy}

Seawater samples were prepared similarly for epifluorescence microscopical analyses in the 4 research projects, but with slight differences in some details. For example, in EB and HOT collections and in CCE sampling prior to October 2008, we analyzed a separate $50 \mathrm{ml}$ sample preserved with paraformaldehyde ( $0.5 \%$ final concentration) to assess nanoplankton (small-volume [SV] samples, below). In later cruises, and after negligible differences were found between preservation treatments, nanoplankton slides were

Table 1. Summary of sampling areas, cruise months, sampling plans and number of samples collected for the current study. Projects: Equatorial Biocomplexity (EB); California Current Ecosystem, Long Term Ecological Research (CCE-LTER) program, including the California Cooperative Oceanic Fisheries Investigations (CalCOFI) component; the Flux and Zinc Experiments in the Costa Rica Dome (CRD); the Hawaii Ocean Time-series (HOT) program

\begin{tabular}{|lccc|}
\hline Project & Location & Cruises & Type \\
\hline EB & Equatorial Pacific & Dec 2004, Sep 2005 & Transect sampling \\
CCE-LTER & California Current & May 2006, Apr 2007, Oct 2008 & $\begin{array}{c}\text { Process cruises } \\
\text { Quarterly, station grid }\end{array}$ \\
CalCOFI/CCE-LTER & California Current & Nov 2004 to Oct 2010 & Process cruise \\
CRD & Costa Rica Dome, & Jun-Jul 2010 & 384 \\
HOT & upwelling region & Oct 2004 to Jan 2009 & Monthly, fixed station \\
\hline
\end{tabular}


prepared from $50 \mathrm{ml}$ subsamples of the water preserved for microplankton analyses (large-volume [LV] samples). For the latter, $500 \mathrm{ml}$ samples were gently collected from the CTD and immediately preserved according to a modified protocol of Sherr \& Sherr (1993). The samples were first preserved with $260 \mu \mathrm{l}$ of alkaline Lugol's solution, immediately followed by $10 \mathrm{ml}$ of buffered formalin and $500 \mu \mathrm{l}$ of sodium thiosulfate, with gentle mixing between each addition. Preserved samples were shielded from light and left to rest at room temperature for $1 \mathrm{~h}$. After this fixation period, $1 \mathrm{ml}$ of proflavin $(0.33 \% \mathrm{w} / \mathrm{v})$ was added, and the samples were stored in the dark for an additional hour. Immediately prior to filtration, the preserved samples were stained with $1 \mathrm{ml}$ of 4',6-diamidino-2phenylindole (DAPI; $0.01 \mathrm{mg} \mathrm{ml}^{-1}$ ). Cells in the $50 \mathrm{ml}$ SV aliquots (or separate paraformaldehyde-preserved samples with comparable proflavin and DAPI staining) were filtered onto $25 \mathrm{~mm}$ black polycarbonate filters with $0.8 \mu \mathrm{m}$ pores. The remaining $450 \mathrm{ml} \mathrm{LV}$ aliquots, or less when plankton concentrations were visibly high on the SV filters, were concentrated onto $25 \mathrm{~mm}$ black polycarbonate filters with $8.0 \mu \mathrm{m}$ pores. We placed a pre-wetted $10 \mu \mathrm{m}$ nylon backing filter under all polycarbonate filters to promote even cell distribution, and filtered the samples under gentle vacuum pressure $(<100 \mathrm{~mm} \mathrm{Hg})$. Each filter was then mounted onto glass slides with 1 drop of Type DF immersion oil and a No. 2 cover slip, and the prepared slides were frozen at $-80^{\circ} \mathrm{C}$ for later analysis in the lab.

Slides were digitally imaged using a Zeiss Axiovert 200 M inverted compound microscope equipped for high-throughput epifluorescence microscopy with motorized focus drive, stage, objective and filters. Digital images were acquired with a Zeiss AxioCam MRc black and white 8-bit CCD camera (Zeiss AxioCam HRc color CCD camera for EB and HOT). All microscope functions were controlled by Zeiss Axiovision software. Image acquisition was automated, and exposure times were automatically controlled to avoid over exposure. SV samples (50 ml aliquots) were viewed at $630 \times$ magnification, and LV samples (450 ml aliquots) were viewed at $200 \times$ magnification. A minimum of 20 random positions were imaged for each slide, with each position consisting of 3 to $4 \mathrm{flu}-$ orescent channels: chl a, DAPI, proflavin (SV and LV samples) and phycoerythrin (SV samples only) - red, blue, green and orange, respectively.

The combined images were processed and analyzed using ImagePro software to semi-automate the enumeration of eukaryotic cells larger than $1.5 \mu \mathrm{m}$ in length (Taylor et al. 2015). Whenever possible, >300 cells were counted for each slide. Poor-quality images were discarded. Cells were automatically segmented from the background and outlined; user interaction was then required to check each image, split connected cells, outline cells that did not auto-segment from the background and delete artifacts and detritus that the software had incorrectly outlined. Autotrophic cells were identified by the presence of chl a (red autofluorescence under blue light excitation), generally clearly packaged in defined chloroplasts. Obvious heterotrophic cells with recently consumed prey were manually excluded from the autotrophs.

Cells were also grouped into 3 size categories (Pico,

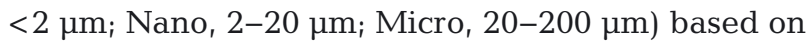
the lengths of their longest axis. Microscopical size analysis alone defined the composition of Nano and Micro categories. However, the size class for autotrophic picophytoplankton (A-Pico) also included contributions from the photosynthetic bacteria, Prochlorococcus (PRO) and Synechococcus (SYN), and $<1.5 \mu \mathrm{m}$ picoautotrophic eukaryotes (PEUK) enumerated by flow cytometry (described below), in addition to the autotrophic eukaryotic cells between 1.5 and $2.0 \mu \mathrm{m}$ measured by epifluorescence microscopy.

For all size categories, biovolumes $\left(\mathrm{BV}_{;} \mu \mathrm{m}^{3}\right)$ were calculated from the length (L) and width (W) measurements of each cell using the geometric formula of a prolate sphere $(\mathrm{BV}=0.524 \times \mathrm{LWH})$, assuming $\mathrm{H}=$ W, except for the EB study where it was found that $\mathrm{H}=0.5 \mathrm{~W}$ for non-diatom cells (Taylor et al. 2011). Biomass was calculated as carbon $\left(\mathrm{C}_{i}\right.$ pg cell $\left.{ }^{-1}\right)$ using the equations of Menden-Deuer \& Lessard (2000): $\mathrm{C}=0.288 \mathrm{BV}^{0.811}$ for diatoms and $\mathrm{C}=0.216 \mathrm{BV}^{0.939}$ for non-diatoms.

\section{Picoplankton analysis by flow cytometry}

Samples $(2 \mathrm{ml})$ for flow cytometry (FCM) analysis of phototrophic bacteria, PRO and SYN, heterotrophic bacteria (H-Bact) and PEUK were preserved with $0.5 \%$ paraformaldehyde (final concentration) and flash frozen in liquid nitrogen. On shore, the samples were stored at $-80^{\circ} \mathrm{C}$, then thawed in batches and stained with Hoechst $34442\left(1 \mu \mathrm{g} \mathrm{ml}^{-1}\right.$, final concentration) immediately prior to analysis (Campbell \& Vaulot 1993, Monger \& Landry 1993). The analyses were conducted at the SOEST Flow Cytometry Facility (www.soest.hawaii.edu/sfcf) using a BeckmanCoulter Altra flow cytometer equipped with a Harvard Apparatus syringe pump to quantify volume sampled and 2 argon ion lasers tuned to UV (200 mW) and $488 \mathrm{~nm}(1 \mathrm{~W})$ excitation. Fluorescence signals were collected using filters for Hoechst-bound DNA, 
phycoerythrin and chlorophyll $a$, all normalized to internal standards of 0.5 and $1.0 \mu \mathrm{m}$ yellow-green polystyrene beads (Polysciences). Listmode data files (FCS 2.0 format) of cell fluorescence and light-scatter properties were acquired with Expo32 software (Beckman-Coulter) and used with FlowJo software (Tree Star, www.flowjo.com) to define populations based on DNA signal (all cells), absence of photosynthetic pigments (H-Bact), presence of chl a (PEUK, PRO and SYN), presence of phycoerythrin (SYN) and forward angle light scatter (FALS; relative size).

Abundance estimates of PRO, SYN and H-Bact from FCM analyses were converted to carbon biomass using carbon per cell conversions estimated for each taxonomic group using bead-normalized FALS as a relative measure of cell biovolume (Linacre et al. 2010, 2012). Estimates of cell carbon content were made using mean open-ocean, mixed-layer estimates of 10, 32 and $101 \mathrm{fg} \mathrm{C}^{-1 l^{-1}}$ as a starting point for H-Bact, PRO and SYN, respectively (Garrison et al. 2000, Brown et al. 2008). Then, using the scaling factor FALS ${ }^{0.55}$ (Binder et al. 1996, Landry et al. 2003), the carbon:cell content ratio was determined for each category and for each cruise and depth from the taxon-specific mean cell carbon values and the FALS ratio $\left(\text { FALS }_{\text {sample }}: \text { FALS }_{\text {mean }}\right)^{0.55}$.

Cell counts from both microscopy and flow cytometry were used to assess abundances of PEUK in 2 size classes, $1.5-2$ and $<1.5 \mu \mathrm{m}$. The former was determined directly from microscopical counts. The latter was determined from the difference between the total small eukaryotic cells counted by flow cytometry and the total microscopy count of $<5 \mu \mathrm{m}$ cells. Assuming that the cell diameters of $<1.5 \mu \mathrm{m}$ PEUK were in the range of 0.8 and $1.5 \mu \mathrm{m}$, a mean biomass estimate of $192 \mathrm{fg} \mathrm{C} \mathrm{cell}^{-1}$ was computed for the cells in this size category (Menden-Deuer \& Lessard 2000). These were then combined with $>1.5 \mu \mathrm{m}$ PEUK biomass measured by microscopy to estimate total PEUK carbon. Total A-Pico biomass is the sum of SYN and PRO carbon measured from FCM and total carbon of PEUK.

\section{Data analysis}

Biomass and abundance estimates of microbial community size class, composition and H-Bact specific growth rates were binned using either total chl a

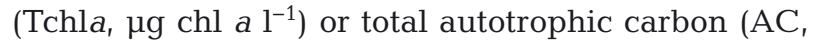
$\mu \mathrm{g} \mathrm{C}{ }^{-1}$; the biomass sum of PRO, SYN and eukaryotes) as a proxy for system richness. AC and Tchla data were averaged in 13 and 15 bins, respectively, each bin cutoff increasing by $50 \%$ relative to the pre- vious. Chl a bins ranged from $<0.06$ to $>11.6 \mu \mathrm{g}$

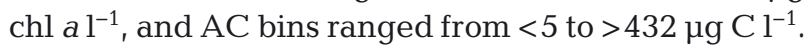
All errors $( \pm)$ are standard errors of the mean (SEM).

To investigate the variability of A-Pico biomass with respect to biotic and abiotic factors, we developed and ran generalized additive models (GAMs) coded in R (freely downloaded through R software, www.r-project.org) using the 'mgcv' package (http:// cran.r-project.org/web/packages/mgcv/). Data for the model runs consisted only of samples where we had data for both the biotic and abiotic measurements $(\mathrm{n}=728)$. The sample data were then split into 2 parts, based on the point where A-Pico begins to decline $\left(\mathrm{AC}\right.$ bin $=45 \mu \mathrm{g} \mathrm{C} \mathrm{l^{-1 }}$ ), to create a poorer trophic state dataset $(n=520)$ and richer trophic state dataset $(\mathrm{n}=208)$. Biotic factors consisted of Tchla, photosynthetic nano and microplankton (A-Nano, AMicro) and heterotrophic bacteria, nano and microplankton (H-Bact, H-Nano, H-Micro). Abiotic factors consisted of temperature, salinity and nutrients $\left(\mathrm{NO}_{3}\right.$, $\mathrm{PO}_{4}$ and $\mathrm{SiO}_{3}$ ). Model performance was compared using Akaike's information criterion (AIC; Spiegelhalter et al. 2002) where, for models of the same dataset, the better models have lower AIC.

\section{RESULTS}

\section{Autotrophic biomass and size relationships}

Whether the data are organized in terms of increasing total AC (Fig. 2A) or increasing Tchla (Fig. 2B), they show similar gross features of phytoplankton size-structure variation with increasing biomass. For both A-Nano and A-Micro, increasing carbon biomasses are well described by fitted power functions on the log-log plots. In both cases, the slopes of the relationships are significantly steeper for A-Micro than A-Nano; thus, larger phytoplankton cells emerge as the community dominants at the highest levels of total biomass. In contrast, A-Pico biomass first increases to peak values at intermediate levels of total community biomass then decreases to substantially lower values as community biomass increases further.

On the AC scale (Fig. 2A), A-Pico biomass peaks $\left(11.7 \pm 0.64 \mu \mathrm{g} \mathrm{Cl}^{-1}\right.$; Table 2) around $45-50 \mu \mathrm{g} \mathrm{Cl}^{-1}$ of total phytoplankton biomass before declining by about a factor of $4\left(2.4 \pm 0.29 \mathrm{\mu g} \mathrm{C} \mathrm{l}^{-1}\right)$ at higher AC. Below $50 \mathrm{\mu g} \mathrm{Cl}^{-1}$, A-Pico typically comprises $33-50 \%$ of total AC, while A-Nano contributes $45-60 \%$ and AMicro increases gradually from about 5 to $16 \%$ of total AC (Table 2). At high carbon biomass $>290 \mu \mathrm{g} \mathrm{Cl}^{-1}$, 


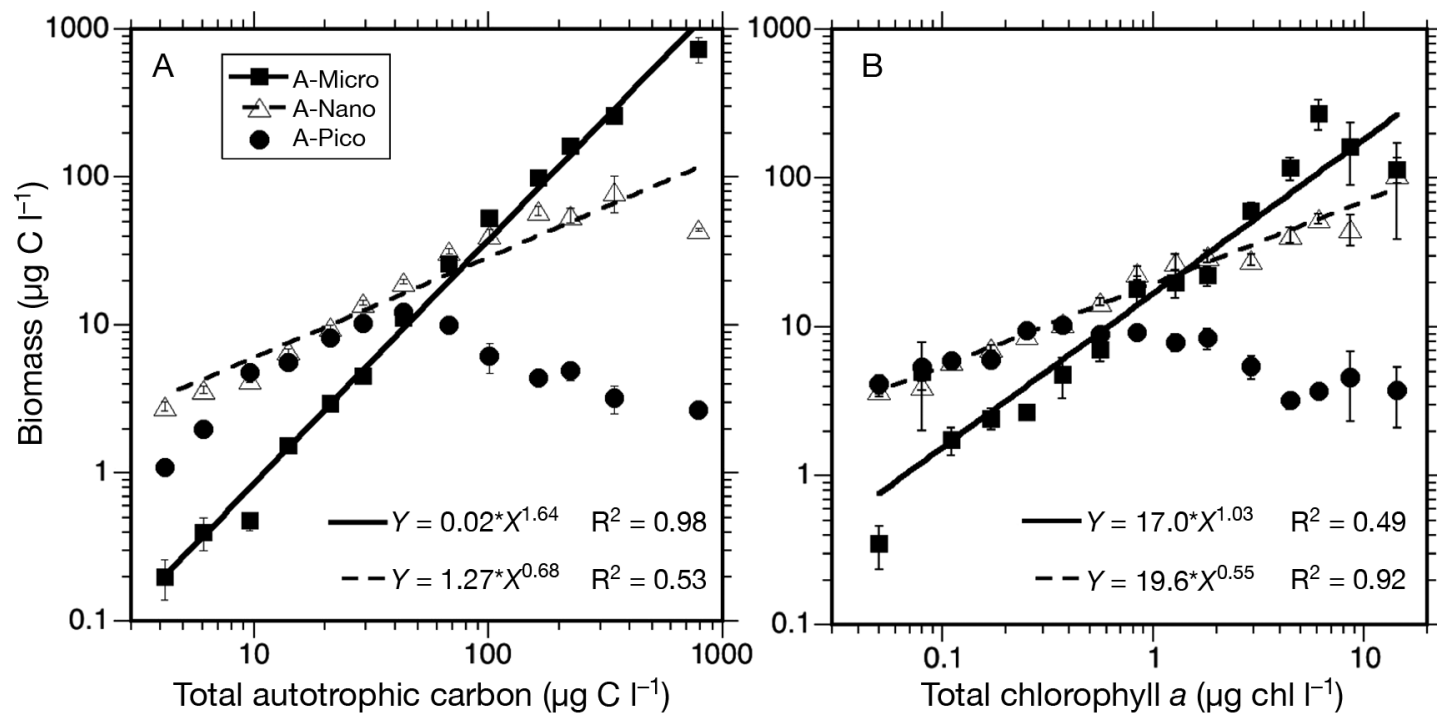

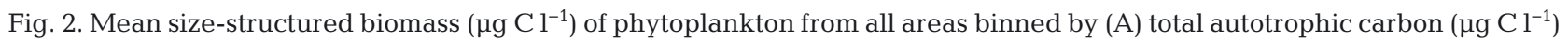
and (B) total chlorophyll a ( $\mu \mathrm{g} \mathrm{chl} \mathrm{a}^{-1}$ ). Size classes are autotrophic picophytoplankton (A-Pico, $\left.0.2-2 \mu \mathrm{m}\right)$, nanophyto-

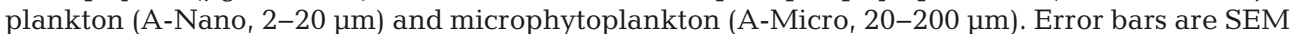

Table 2. Mean biomass estimates and percent contributions of autotrophic size classes for all study regions binned by total autotrophic carbon (AC). Size classes are A-Pico $(0.2-2 \mu \mathrm{m})$, A-Nano $(2-20 \mu \mathrm{m})$ and A-Micro $(20-200 \mu \mathrm{m})$

\begin{tabular}{|c|c|c|c|c|c|c|}
\hline \multirow[t]{2}{*}{$\mathrm{AC}$ bin } & \multicolumn{3}{|c|}{- Biomass $\left(\mu \mathrm{g} \mathrm{Cl}^{-1} \pm \mathrm{SE}\right)-$} & \multicolumn{3}{|c|}{- Contribution $(\%)-$} \\
\hline & A-Pico & A-Nano & A-Micro & A-Pico & A-Nano & A-Micro \\
\hline$<5.0$ & $1.1 \pm 0.13$ & $3.0 \pm 0.20$ & $0.2 \pm 0.07$ & 25.7 & 69.1 & 5.3 \\
\hline 7.5 & $2.0 \pm 0.19$ & $3.7 \pm 0.19$ & $0.4 \pm 0.10$ & 32.9 & 60.4 & 6.7 \\
\hline 11.3 & $4.7 \pm 0.19$ & $4.3 \pm 0.18$ & $0.5 \pm 0.07$ & 49.4 & 45.3 & 5.2 \\
\hline 16.9 & $5.6 \pm 0.20$ & $6.7 \pm 0.20$ & $1.6 \pm 0.11$ & 40.3 & 48.0 & 11.7 \\
\hline 25.3 & $8.1 \pm 0.27$ & $9.9 \pm 0.29$ & $3.0 \pm 0.20$ & 38.8 & 46.8 & 14.4 \\
\hline 38 & $10.3 \pm 0.51$ & $14.0 \pm 0.49$ & $4.7 \pm 0.40$ & 35.6 & 48.4 & 16.0 \\
\hline 57 & $11.7 \pm 0.64$ & $19.8 \pm 0.61$ & $11.7 \pm 0.74$ & 27.6 & 45.7 & 26.7 \\
\hline 85 & $10.0 \pm 1.17$ & $31.0 \pm 1.44$ & $26.5 \pm 1.78$ & 15.1 & 46.1 & 38.8 \\
\hline 128 & $5.8 \pm 1.33$ & $40.7 \pm 3.42$ & $53.3 \pm 3.81$ & 5.8 & 40.8 & 53.4 \\
\hline 192 & $4.4 \pm 0.39$ & $59.4 \pm 4.31$ & $98.9 \pm 5.21$ & 2.8 & 36.9 & 60.4 \\
\hline 288 & $5.0 \pm 0.73$ & $56.4 \pm 6.67$ & $163 \pm 7.94$ & 2.2 & 25.2 & 72.6 \\
\hline 432 & $2.9 \pm 0.70$ & $80.4 \pm 22.2$ & $259 \pm 21.8$ & 0.9 & 23.1 & 76.0 \\
\hline$>432$ & $2.4 \pm 0.29$ & $44.6 \pm 0.88$ & $739 \pm 144$ & 0.4 & 6.7 & 92.9 \\
\hline
\end{tabular}

A-Micro exceeds $75 \%$ of $\mathrm{AC}$, and A-Nano and A-Pico decline to $<25 \%$ and $<1 \%$, respectively (Table 2 ). On the Tchla scale (Fig. 2B), peak A-Pico biomass (10.4 \pm

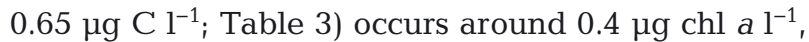
below which A-Pico and A-Nano each contribute a relatively consistent $40-50 \%$ to total AC (Table 3).

Closer inspection of the data in Fig. 2A,B (Tables 2 \& 3) reveals that certain interpretations are sensitive to the vagaries of data sorting, especially at the lower and upper ends of the biomass scales where data density is most sparse. For instance, A-Nano appears to dominate at low total AC (Fig. 2A, Table 2), while $\mathrm{A}-\mathrm{Pico}$ and $\mathrm{A}-\mathrm{Nano}$ are more equal and co-dominant at low Tchla (Fig. 2B, Table 3). This difference arises from the fact that $77 \%$ of the samples for the 2 lowest $\mathrm{AC}$ bins come from the CCE, where the mixed-layer abundances of PRO rarely reach levels observed in the adjacent subtropical waters (HOT). In contrast, $58 \%$ of the data for the 2 lowest Tchla bins comes from HOT, and a disproportionate percentage $(78 \%)$ of that is from summertime sampling months when the chl:AC ratio of phytoplankton is seasonally lowest (Pasulka et al. 2013). At the high end of the biomass spectra, the highest Tchla samples are strongly dominated by large (micro-sized) diatoms, while the highest AC samples captured a coastal bloom of nano-sized dinoflagellates (at moderate $6 \mu \mathrm{g} \mathrm{chl} \mathrm{a} \mathrm{l}^{-1}$ ). Such differences influence the relative contributions of size classes and taxa to the high biomass community, and argue for conservative interpretations at the data extremes.

Despite the above cautions, the Tchla and AC data are strongly related overall (Fig. 3). The power function of AC versus Tchla has a slope $(=0.64)$ significantly less than 1.0 at $p=0.05$. Consequently, the ratio of AC:Tchla has a negative slope of $-0.36(=0.64-1.0)$, giving mixed-layer values that vary monotonically from $\sim 170$ for the lowest Tchla in open-ocean samples to $\sim 20$ for the richest coastal samples (Fig. 3). In subsequent plots, we use only Tchla as the independ- 
Table 3. Mean biomass estimates and percent contributions of autotrophic size

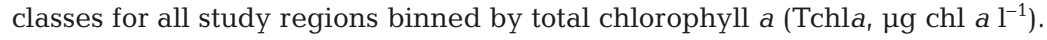
Size classes are A-Pico $(0.2-2 \mu \mathrm{m})$, A-Nano $(2-20 \mu \mathrm{m})$ and A-Micro $(20-200 \mu \mathrm{m})$. Data sorting intervals are defined by the intervals between upper values for adjacent bins

\begin{tabular}{|c|c|c|c|c|c|c|}
\hline \multirow{2}{*}{$\begin{array}{l}\text { Tchla } \\
\text { bin }\end{array}$} & \multicolumn{3}{|c|}{- Biomass $\left(\mu \mathrm{g} \mathrm{Cl}^{-1} \pm \mathrm{SE}\right)-$} & \multicolumn{3}{|c|}{ Contribution $(\%)$} \\
\hline & A-Pico & A-Nano & A-Micro & A-Pico & A-Nano & A-Micro \\
\hline$<0.06$ & $4.2 \pm 0.57$ & $3.8 \pm 0.33$ & $0.4 \pm 0.11$ & 48.0 & 47.4 & 4.6 \\
\hline 0.09 & $5.4 \pm 0.37$ & $4.1 \pm 0.28$ & $5.0 \pm 2.95$ & 47.0 & 38.3 & 14.7 \\
\hline 0.13 & $6.0 \pm 0.23$ & $6.0 \pm 0.43$ & $1.8 \pm 0.37$ & 47.2 & 43.6 & 9.2 \\
\hline 0.20 & $6.0 \pm 0.28$ & $7.3 \pm 0.28$ & $2.4 \pm 0.40$ & 39.0 & 49.0 & 12.0 \\
\hline 0.30 & $9.6 \pm 0.54$ & $8.8 \pm 0.33$ & $2.7 \pm 0.18$ & 42.6 & 44.6 & 12.8 \\
\hline 0.46 & $10.4 \pm 0.65$ & $10.6 \pm 0.52$ & $4.8 \pm 1.44$ & 41.6 & 46.8 & 11.6 \\
\hline 0.68 & $8.9 \pm 0.49$ & $14.8 \pm 0.76$ & $7.0 \pm 1.15$ & 32.4 & 51.5 & 16.1 \\
\hline 1.03 & $9.2 \pm 0.75$ & $23.2 \pm 2.35$ & $18.0 \pm 3.99$ & 25.1 & 49.6 & 25.3 \\
\hline 1.54 & $7.9 \pm 1.07$ & $27.7 \pm 3.26$ & $20.0 \pm 4.35$ & 18.5 & 52.2 & 29.4 \\
\hline 2.30 & $8.4 \pm 1.35$ & $30.1 \pm 2.72$ & $22.1 \pm 3.39$ & 17.5 & 51.9 & 30.6 \\
\hline 3.46 & $5.4 \pm 0.93$ & $28.6 \pm 2.42$ & $60.6 \pm 7.75$ & 6.8 & 34.5 & 58.7 \\
\hline 5.19 & $3.2 \pm 0.41$ & $41.7 \pm 4.78$ & $117 \pm 19.8$ & 3.4 & 32.7 & 63.9 \\
\hline 7.78 & $3.7 \pm 0.46$ & $53.7 \pm 4.22$ & $274 \pm 61.9$ & 2.5 & 28.4 & 69.2 \\
\hline 11.7 & $4.6 \pm 2.27$ & $45.9 \pm 10.6$ & $164 \pm 73.9$ & 4.7 & 28.4 & 66.9 \\
\hline$>11.7$ & $3.8 \pm 1.65$ & $106 \pm 67.3$ & $115 \pm 22.1$ & 2.3 & 38.1 & 59.6 \\
\hline
\end{tabular}

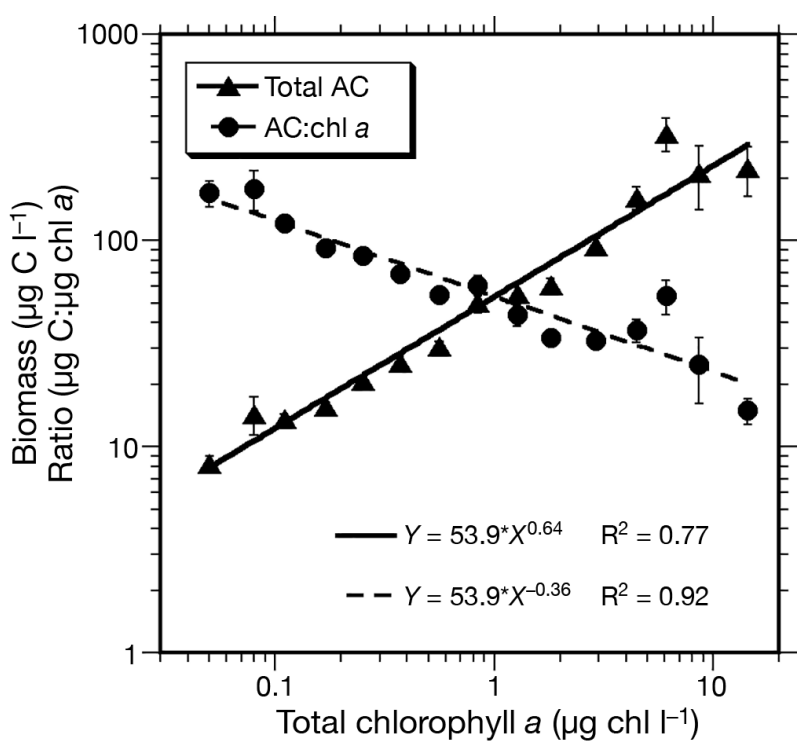

Fig. 3. Relationships between phytoplankton biomass ( $\mu \mathrm{g} \mathrm{C}$ $\mathrm{l}^{-1}$ ) and total chlorophyll $\mathrm{a}\left(\mu \mathrm{g} \mathrm{chl} \mathrm{a} \mathrm{l}^{-1}\right)$ in the study region. AC: autotrophic carbon. Error bars are SEM

ent $\left(x^{-}\right)$axis because Tchla is the more broadly used metric of phytoplankton biomass, because it is measured with higher accuracy and precision than $\mathrm{AC}$, and because it is entirely independent of the carbon biomass measurements on the dependent $(y-)$ axis.

\section{Community composition}

The structural changes that occur with increasing phytoplankton biomass alter taxonomic composition as well as size class distribution (Fig. 4). Opposing trends in the relative importance of PRO and diatoms are among the expected patterns. The data show that PRO contributes $>40 \%$ to phytoplankton carbon in samples

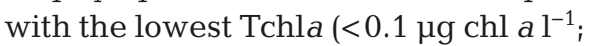
Fig. 4), which come mainly from subtropical waters during summer (HOT). This is followed by a sharp drop off of PRO with increasing phytoplankton biomass, such that PRO comprises no more than a few percent of total $\mathrm{AC}$ in waters with $>1 \mu \mathrm{g}$ chl a $\mathrm{l}^{-1}$. Conversely, diatoms increase in relative importance to total AC from a few percent at low Tchla to $60-80 \%$ in samples collected at the highest Tchla concentrations. As PRO initially declines with increasing trophic richness, SYN and PEUK fill in to maintain the relatively consistent $\sim 40 \%$ contribution of A-Pico to AC biomass seen in Fig. 2B up to $\sim 0.4 \mu \mathrm{g} \mathrm{chl} \mathrm{a} \mathrm{l}^{-1}$, but ultimately, they too decline markedly in relative importance in the samples from richer waters. Significant concentrations of cyanobacteria (CYANO), representing the combined biomass estimates for $\mathrm{N}_{2}$-fixing Trichodesmium spp. (micro-sized filaments) and Crocosphera spp. (nano-sized cells), occur sporadically in oligotrophic subtropical waters sampled mainly during summer, and thus also appear as expected only at the lower end of the trophic richness gradient.

In contrast to the substantial changes in biomass contributions seen for the taxa mentioned above, the board category of phytoflagellates, including prymnesiophytes (PRYM), autotrophic dinoflagellates (ADINO) and unidentified autotrophic flagellate taxa (A-FLAG), comprise a relatively large and consistent component of the phytoplankton community (Fig. 4). Some differences can be seen at the extremes, such as reduced A-DINO and more PRYM at the lower end of the Tchla range and the reverse at the higher end. Also, as previously noted, a coastal A-DINO bloom dominates the data at $6 \mu \mathrm{g} \mathrm{chl} \mathrm{a} \mathrm{l}^{-1}$ or in the highest biomass category if the data are plotted on an ascending AC scale. Regardless, for $>2$ orders of magnitude in total biomass variability across different systems, the combined phytoflagellates account for $\sim 50 \%$ or more of total phytoplankton community biomass (Fig. 4).

For the full data set, populations comprising the APico show varying biomass responses to increasing Tchla (Fig. 5), but all decline under the richer trophic 


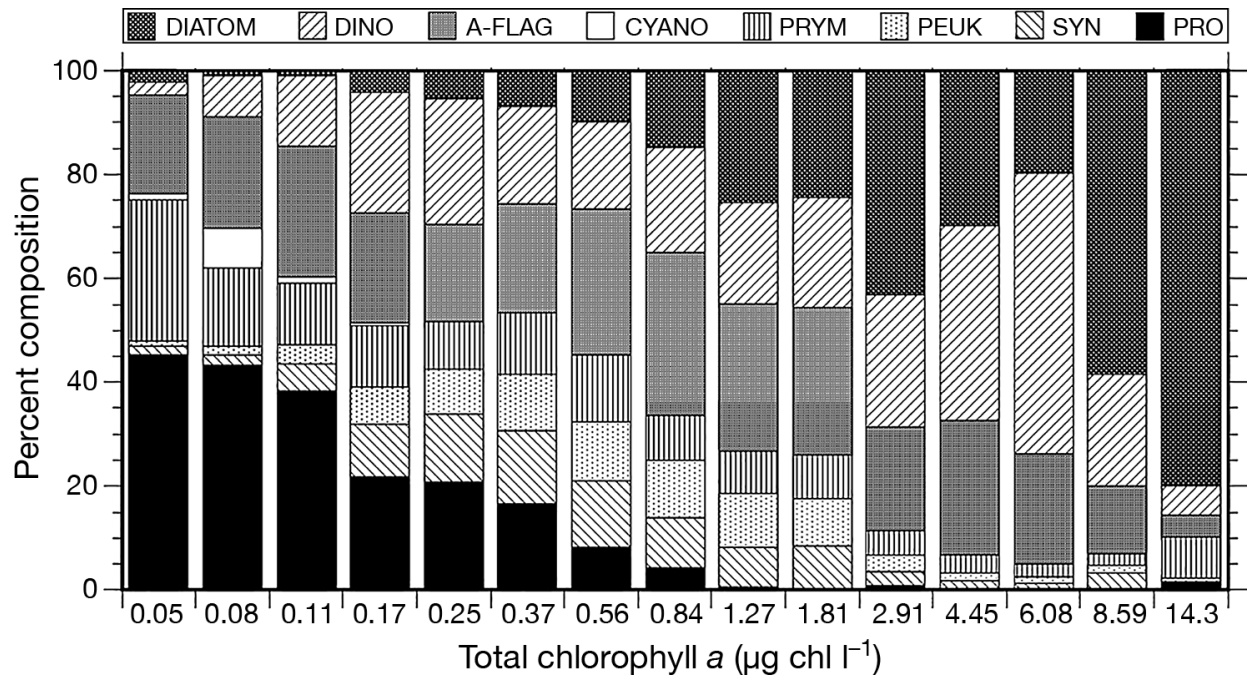

Fig. 4. Percent contribution of phytoplankton groups to total phytoplankton carbon biomass binned by total chlorophyll a

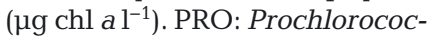
cus spp., SYN: Synechococcus spp., PEUK: picoeukaryotes, PRYM: prymnesiophytes, CYANO: $\mathrm{N}_{2}$-fixing cyanobacteria (Trichodesmium, Crocosphera spp.), A-FLAG: other autotrophic flagellates, DINO: dinoflagellates, DIATOM: diatoms

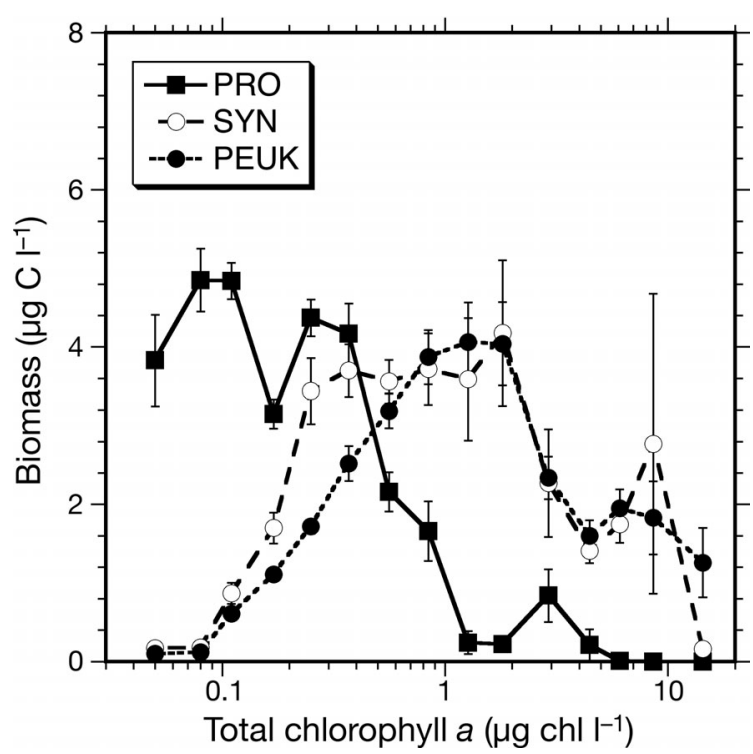

Fig. 5. Biomass contributions of picophytoplankton groups binned by total chlorophyll a $\left(\mu \mathrm{g} \mathrm{chl} \mathrm{a}^{-1}\right)$. PRO: Prochlorococcus spp., SYN: Synechococcus spp., PEUK: picoeukaryotes. Error bars are SEM

conditions. PRO shows a broad biomass maximum of 4-5 $\mu \mathrm{g} \mathrm{Cl}^{-1}$ at low Tchla, but declines precipitously,

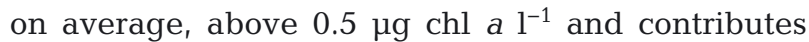
negligibly above $5 \mu \mathrm{g} \mathrm{chl} \mathrm{a} \mathrm{l}^{-1}$. SYN and PEUK both increase from their lowest values at low Tchla, achieve maximal values of $\sim 4 \mu \mathrm{C} \mathrm{Cl}^{-1}$ at intermediate Tchla, and decline to about half of their maximal biomass at high Tchla. SYN precedes PEUK in rising to maximum values at $\sim 0.2$ versus $0.8 \mu \mathrm{g} \mathrm{chl} a \mathrm{l}^{-1}$, but they decline similarly above $2 \mu \mathrm{g} \mathrm{chl} \mathrm{a} \mathrm{l}^{-1}$ (Fig. 5).

Across the range of biomass variability over which the 4 systems in our study can be compared (i.e. up to $\sim 0.5 \mu \mathrm{g} \mathrm{chl} \mathrm{a} \mathrm{l}^{-1}$ ), A-Pico populations display regional differences in mean concentrations and responses to increased biomass (Fig. 6, Table 4). At similar Tchla, subtropical Pacific waters (HOT) have the highest concentrations of PRO and the lowest concentrations of SYN and PEUK of any of the systems (Fig. 6A). Equatorial Pacific waters (EB; Fig. 6B) have PRO concentrations most similar to the subtropics, but SYN and PEUK are an order of magnitude higher. The CRD (Fig. 6C) and CCE (Fig. 6D), both on the eastern margin of the North Pacific, have similar lower PRO concentrations, a factor of 2-3 lower than HOT at comparable Tchla (Table 4). In the CRD, concentrations of SYN and PEUK are notably enhanced, exceeding PRO biomass, at the higher Tchla concentrations sampled. In the CCE, SYN and PEUK concentrations reflect 2 regional influences, being more like HOT in the lowest Tchla samples (i.e. typically oligotrophic open ocean) and more like the CRD at the higher values (i.e. typically coastal upwelling influence).

\section{Heterotrophic bacteria and nanograzers}

Biomasses of H-Bact and nano-sized protistan grazers (H-Nano, 2-20 $\mu \mathrm{m}$ non-plastidic protists) both increase 4 - to 5 -fold over the sampled range of Tchla (Fig. 7). On the lower end of the scale, up to $\sim 1 \mu \mathrm{g} \mathrm{chl} \mathrm{a} \mathrm{l}^{-1}$, mean mixed-layer carbon concentrations of $\mathrm{H}$-Bact are comparable in magnitude to those of A-Pico, both approximately doubling over the biomass interval (Figs. 2B \& 6). However, given the decline in A-Pico biomass in samples collected at higher Tchla, H-Bact carbon exceeds A-Pico by a factor of 5 
Table 4. Results of 1-way ANOVA with Tukey post hoc tests comparing relative biomass contributions of taxonomic groups within the autotrophic picophytoplankton size class (A-Pico; $0.2-2 \mu \mathrm{m}$ ) among regions. p-values are shown when differences in overlapping biomass ranges are significant $(\mathrm{p}<0.05)$; ns: not significant. Taxonomic groups are Prochlorococcus (PRO), Synechococcus (SYN) and picoeukaryotes (PEUK). Data sources as in Fig. 1

\begin{tabular}{|c|c|c|c|c|c|c|c|c|c|}
\hline & \multicolumn{3}{|c|}{$\% \mathrm{PRO}$} & \multicolumn{3}{|c|}{$\%$ SYN -} & \multicolumn{3}{|c|}{$\%$ PEUK } \\
\hline & HOT & EB & CRD & $\mathrm{HOT}$ & EB & CRD & HOT & EB & CRD \\
\hline EB & 0.004 & & & ns & & & 0.005 & & \\
\hline CRD & $<0.001$ & 0.007 & & $<0.001$ & 0.009 & & $<0.001$ & ns & \\
\hline CCE & $<0.001$ & $<0.001$ & $\mathrm{~ns}$ & $<0.001$ & 0.046 & $\mathrm{~ns}$ & $<0.001$ & $<0.001$ & 0.006 \\
\hline
\end{tabular}

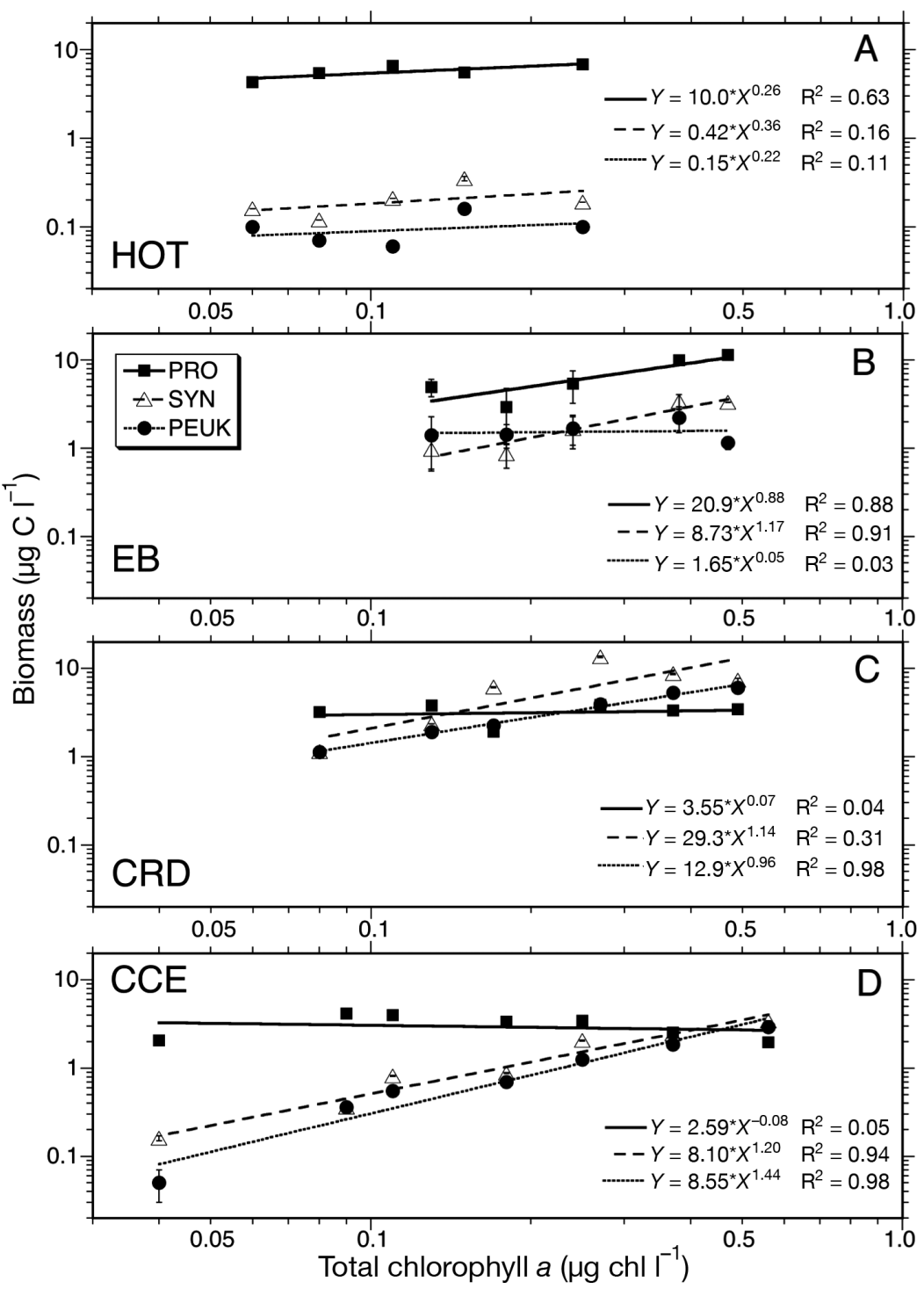

Fig. 6. Variability in the relationships of picophytoplankton biomass to total chlorophyll a in the study region. PRO: Prochlorococcus spp., SYN: Synechococcus spp., PEUK: picoeukaryotes. (A) HOT: Hawaii Ocean Time-series (Stn ALOHA, subtropical Pacific); (B) EB: Equatorial Biocomplexity (equatorial Pacific); (C) CRD: Costa Rica Dome; (D) CCE: California Current Ecosystem. Error bars are SEM at the high end of the biomass scale. Mean mixed-layer biomass of H-Micro (>20 $\mu \mathrm{m}$ non-plastidic protists) rises more sharply than either $\mathrm{H}$-Bact or $\mathrm{H}$ Nano, increasing 20-fold from $\sim 1.5$ to $30 \mu \mathrm{g} \mathrm{Cl}^{-1}$ over the range of Tchla. We did not plot these data in Fig. 7 because the H-Micro category is missing the contributions of large ciliates, which are poorly preserved by the epifluorescence slide-making protocol (Taylor et al. 2011) and because our focus is more on the components of pico-sized prey and their likely nano-sized flagellate grazers.

\section{Generalized additive models}

For each of the 3 datasets examined with GAMs, the biological variables explain significantly higher percentages of deviance than the abiotic variables (full data [All]: 48 versus $24 \%$; low trophic [Poor]: 42 versus 29\%; high trophic [Rich]: 73 versus $45 \%$, respectively; Table 5). In addition, the combined GAMs with both biotic and abiotic variables only modestly improve the deviance explained by the models for biotic variables only, although the significance of relationships for individual variables is altered. For example, the p-values for Tchla are substantially improved in the combined All and Poor $\left(<45 \mu \mathrm{g} \mathrm{C} \mathrm{l}^{-1}\right.$ ) models compared to the biology-only models for the same data, while the opposite is the case for most of the abiotic variables. Overall, 2 variables, A-Micro and H-Bact, show the strongest and most consistent (typically $\mathrm{p}<0.0001$ ) relationships to A-Pico biomass for Poor and Rich subsets of the data, and for All Data combined (Table 5). For the high biomass Rich portion of the data, which mostly comes from the CCE, it is particularly notable that factors that would reasonably be expected to be strong indicators of ecosystem variability in the region (namely Tchla, temperature, salinity and nutrients) show no significant relationships to A-Pico biomass in the GAM that includes all measured variables (Table 5). 


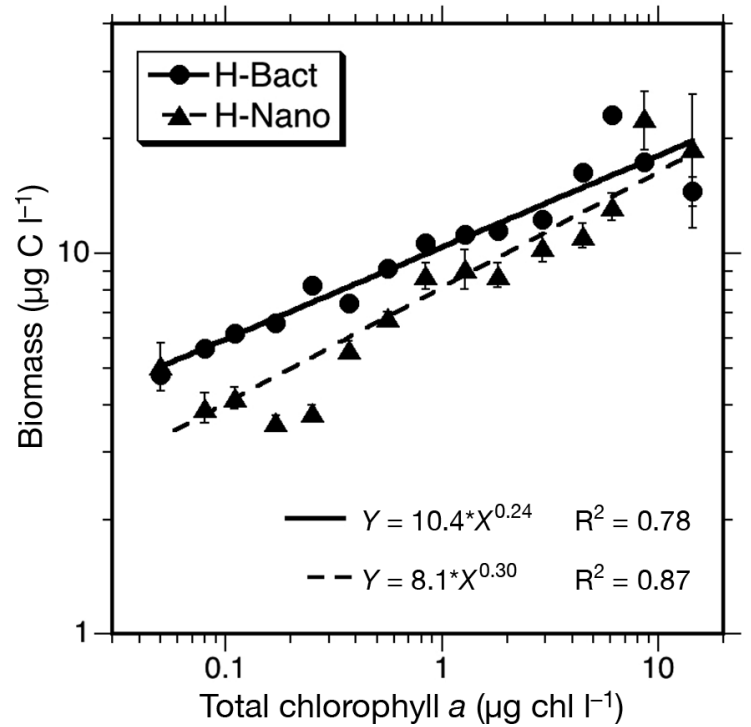

Fig. 7. Mean size-structured biomass $\left(\mu \mathrm{g} \mathrm{Cl}^{-1}\right)$ of heterotrophic bacteria (H-Bact) and heterotrophic nanoflagellates (H-Nano) from all areas binned by total chlorophyll a ( $\mu \mathrm{g}$ chl $\left.a l^{-1}\right)$. Error bars are SEM

\section{DISCUSSION}

The present study reveals coherent trends in phytoplankton size structure with increasing biomass across environmental gradients in the southern CCE and adjacent open-ocean regions. The biomass of larger phytoplankton increases dramatically, as expected, under rich coastal upwelling conditions. However, we found a significant decrease of picophytoplankton that is not predicted either by 'stepaddition' theory (Thingstad 1998) or by the 'rising tide' hypothesis (Barber \& Hiscock 2006). Furthermore, not just PRO, but all functional groups of picophytoplankton (PRO, SYN and PEUK) decreased on average in the richest environments (Fig. 5).

As illustrated in Fig. 2, the general patterns of size variability are robust regardless of whether Tchla or total AC is used as an index of trophic state. Tchla is a useful proxy for system trophic state because it is easily measured, available as global or regional sea surface products (Morel \& Berthon 1989, Behrenfeld \& Falkowski 1997, Pérez et al. 2005) and is positively related to nutrient status (Eppley 1992, Claustre 1994). It is also the more appropriate variable for representing trophic state in the present study because it is measured independently of the carbon biomass values that are plotted against it. While Tchla as an index of phytoplankton carbon biomass can vary greatly with light, nutrients, taxonomic composition and growth rate (Eppley 1972, Cullen 1982, Geider 1987), all of these effects are presumably integrated

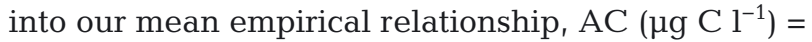
$52.9 \times\left(\mu \mathrm{g} \text { Tchla } \mathrm{l}^{-1}\right)^{0.64}$, which can inform regional models, satellite remote sensing products and ecological process studies where AC is not directly measured.

\section{Phytoplankton size structure}

The biomass structure of phytoplankton communities is determined by a complex interplay of bottomup influences on the physical/chemical growth environment (micro- and macronutrient availability) and

Table 5. Results of generalized additive models to predict autotrophic picophytoplankton (A-Pico) biomass based on 3 variations of the dataset: All data ( $\mathrm{n}=728$ ), Poor trophic state (autotrophic carbon $[\mathrm{AC}]<45 \mu \mathrm{g} \mathrm{C}{ }^{-1}, \mathrm{n}=590$ ) and Rich trophic state $\left(\mathrm{AC}>45 \mu \mathrm{g} \mathrm{C} \mathrm{l}^{-1}\right.$, $\left.\mathrm{n}=138\right)$. Each dataset was modeled with 3 groups of independent variables: biotic (total chlorophyll a [Tchla], autotrophic nano- and microphytoplankton [A-Nano, A-Micro] and heterotrophic bacteria, nano- and microphytoplanton [H-Bact, H-Nano, H-Micro]), abiotic (temperature, salinity, $\mathrm{NO}_{3}, \mathrm{PO}_{4}$ and $\mathrm{SiO}_{3}$ ) and both (biotic + abiotic). AIC: Akaike's information criterion. $\# \mathrm{p}<0.05,{ }^{*} \mathrm{p}<0.01,{ }^{* *} \mathrm{p}<0.001,{ }^{* * *} \mathrm{p}<0.0001$

\begin{tabular}{|c|c|c|c|c|c|c|c|c|c|c|c|c|c|}
\hline & Tchla & A-Nano & A-Micro & H-Bact & H-Nano & H-Micro & Temp & Salinity & $\mathrm{NO}_{3}$ & $\mathrm{PO}_{4}$ & $\mathrm{SiO}_{3}$ & $\begin{array}{c}\text { Deviance } \\
\text { explained (\%) }\end{array}$ & AIC \\
\hline \multicolumn{14}{|l|}{ All data } \\
\hline Biotic & \# & $* * *$ & $* * *$ & $* * *$ & $* *$ & & & & & & & 48 & 2667 \\
\hline Abiotic & & & & & & & $* * *$ & & $* *$ & $* * *$ & $* * *$ & 24 & 5426 \\
\hline Both & $* * *$ & $* *$ & $* * *$ & $* * *$ & * & & & & & $* *$ & $* * *$ & 54 & 2622 \\
\hline \multicolumn{14}{|l|}{ Poor } \\
\hline Biotic & * & $*$ & $* * *$ & $* * *$ & * & $*$ & & & & & & 42 & 2054 \\
\hline Abiotic & & & & & & & $* * *$ & * & $* * *$ & $* * *$ & $* *$ & 29 & 3943 \\
\hline Both & $* * *$ & & $* *$ & $* * *$ & * & * & & & & $*$ & $*$ & 48 & 2021 \\
\hline \multicolumn{14}{|l|}{ Rich } \\
\hline Biotic & & & $* * *$ & $* * *$ & & & & & & & & 73 & 497 \\
\hline Abiotic & & & & & & & $* * *$ & & $* *$ & $* * *$ & $* * *$ & 45 & 1332 \\
\hline Both & & & $* * *$ & $* * *$ & & & & & & & & 72 & 499 \\
\hline
\end{tabular}


top-down trophic impacts on loss rates (Tilman at al. 1982, Hutchins \& Bruland 1998, Calbet \& Landry 2004). At vanishingly low nutrient concentrations, theory predicts that very small cells with high surface:volume ratios will be the strongest competitors for nutrient uptake (Raven 1986, Chisholm 1992, Raven et al. 2005). Even with increasing nutrient input, such competitive dominants are assumed to keep ambient nutrients at levels that limit biomass accumulation of less efficient phytoplankton, until the dominants achieve maximum growth rates and their concentrations are controlled by grazers (Thingstad 1998). Thresholds, where presumptively less efficient competitors begin to increase in absolute and relative importance above a certain concentration of the dominant base community, have been weakly observed for some taxa based on HPLC diagnostic marker pigments (Goericke 2011b), consistent with the step-addition hypothesis. Nonetheless, our data, plotted against Tchla or total AC, failed to show a clear separation of pico- and nanophytoplankton at the low end of the biomass spectrum, as would be predicted. This inconsistency with theory might be explained, in part, by the functional complexity of phytoplankton, notably the widespread occurrence of mixotrophic nanoplankton that do not compete directly with A-Pico for uptake of dissolved inorganic nutrients in oligotrophic systems, but acquire their nutrients by feeding on smaller cells instead (e.g. Sanders 1991, Stoecker 1999, Mitra et al. 2014).

We also note that while picophytoplankton is often assumed to account for most of the phytoplankton biomass and production in oligotrophic ocean systems, that is not always the case when rigorous assessments are made. For example, based on a comprehensive review of literature values available prior to 2000, Agawin et al. (2000) concluded that picophytoplankton accounted for $~ 50 \%$ of phytoplankton biomass in the nutrient-poorest ocean regions. Similarly, Uitz et al. (2010) determined that picophytoplankton contribute a maximal of $45 \%$ to primary production in the ocean's subtropical gyres based on satellite data products and class-specific photophysiological relationships. Mechanical size-fractioning of $\mathrm{chl}$ a can also lead to 2-fold overestimates of the relative importance of picophytoplankton (Landry 2009), due to cells with flexible walls and free chloroplasts from broken cells that squeeze through the nominal $2 \mu \mathrm{m}$ filter pores under pressure.

Where the 'step-addition' (Thingstad 1998) and 'rising-tide' hypotheses (Barber \& Hiscock 2006) clearly differ is in the expected behavior of picophytoplankton with increasing trophic state. According to the former hypothesis, the biomass of competitively dominant picoautotrophs should rise quickly to a dynamic steady-state balance, at which maximum growth rate is offset by losses to highly responsive nanozooplankton grazers. Larger cells are only added to the system once quotas for the smaller size classes are filled (Raimbault et al. 1988). In the contrasting 'rising tide' hypothesis, all types and sizes of phytoplankton can benefit from increased nutrient availability because none are assumed to have achieved their maximum growth rates under typical open-ocean conditions. All therefore increase under favorable conditions, although the rate of increase is far greater for larger cells. Barber \& Hiscock (2006) demonstrated that the 'rising tide' hypothesis adequately explained the observed dynamics (enhanced growth rate and modestly increased abundance) of PRO in response to the IronEx II iron-fertilization experiment in the equatorial Pacific. Such a result would also be expected from Fig. 2, given that the initial ambient AC biomass for the IronEx experiment $\left(\sim 20 \mu \mathrm{g} \mathrm{C} \mathrm{l}^{-1}\right)$ was lower than the level at which picophytoplankton attain peak biomass (Landry et al. 2000).

Among PRO, SYN and PEUK, none increase or level off at phytoplankton concentrations typical of rich coastal environments (Fig. 3). That is, even as phototrophic bacteria decline in coastal waters, there is no compensatory replacement of their role in community size structure by tiny eukaryotes. In contrast, ANanos continue to increase in richer coastal waters, albeit at a slower rate than A-Micros (Fig. 2). The ANano results conform most closely with expectations of the 'rising tide' hypothesis. Even so, however, among the individual components of the nanophytoplankton assemblage in the present data, different groups have varying patterns of increase (flagellates, diatoms) or decrease (prymnesiophytes, cryptophytes, small dinoflagellates) with increasing AC.

\section{Regional differences in community structure}

Although the regions examined in this study are ecologically distinct, they reside in relatively close proximity in the southeastern sector of the North Pacific with fluid boundaries and current systems that should allow for relatively easy population seeding and exchange among them. The California Undercurrent, for example, brings water of eastern tropical Pacific origin north into the southern CCE region (Lynn \& Simpson 1987). Waters with flora of clear subtropical origin occur on the western edge of the California Current and move well inshore in 
the southern California Bight during summertime (Venrick 2002, 2009). Given the many potential routes of population exchange, the differences that arise in community structure and composition can reasonably be interpreted in terms of different selective pressures among the systems examined. Although mechanisms that lead to regional variations in structure and composition are poorly understood and likely complex, here we attempt to infer some possibilities from the similarities and differences that we observe.

Landry \& Kirchman (2002) previously noted that the equatorial Pacific is similar to subtropical waters of the North Pacific gyre with respect to picophytoplankton dominance by PRO. The main difference is that the more productive waters of the equatorial region have higher standing stocks of SYN and PEUK superimposed upon the similar concentrations of PRO (Landry 2002), as would be expected from 'step-addition' hypothesis (Thingstad 1998). These observations also apply to the present comparisons of HOT and EB data (Fig. 6), which are entirely independent of the previously analyzed data. The HOT and EB regions are contrasting physical-chemical systems in many respects (iron-sufficient, oligotrophic downwelling versus chronically iron-limited, open-ocean upwelling). Yet, these fundamentally different physical-chemical conditions seem to minimally affect dominance structure of picophytoplankton in the 2 areas.

In contrast, at similar concentrations of Tchla, picophytoplankton compositions differ substantially in the CCE and CRD from the HOT and EB regions (Fig. 6). As discussed more fully below, increased grazing pressure due to enhanced activity of the microbial loop might explain the reduced abundance of PRO in these 2 systems. Mechanistically, the strong, shallow oxygen zone underlying the CRD upwelling system could be a source of substantial dissolved organic input into the euphotic zone to stimulate microbial activity. Similarly, rapid lateral advective transport by coastal jets, filaments and mesoscale eddies in the CCE region (Pelaez \& McGowan 1986, Thomas \& Strub 1990) are mechanisms with potential to bring significant subsidies of labile dissolved substrates from productive coastal upwelling cells to waters 100s of kilometers offshore. In addition, however, the unique dominance pattern and very high SYN abundances in the CRD region (see also Li et al. 1983, Saito et al. 2005, Gutiérrez-Rodríguez et al. 2014) argue for a different resource environment than the iron and macro-nutrient limited waters of the equatorial and subtropical Pacific, where PRO predominates. Copper, cadmium and zinc-iron limitations have been advanced as possible explanations for the unique CRD phytoplankton structure (Franck et al. 2003, Saito et al. 2005). Chappell et al. (2016) specifically argued that low Zn:P ratios in the CRD may select for phytoplankton, like SYN, with low Zn requirements.

\section{Biomass decrease of picoautotrophs}

Previous studies with flow cytometry and taxonspecific pigments in the California Current have documented offshore maxima and in-shore declines of photosynthetic bacteria, PRO and SYN (Collier \& Palenik 2003, Goericke 2011a). Similar patterns have also been noted across strong environmental gradients in the Arabian Sea (Campbell et al. 1998) and broad ecological provinces of the oceans (e.g. Li 2009). Taylor et al. (2012) have additionally demonstrated fine-scale distributions of PRO and SYN across an enriched front in the CCE that capture much of the size-structure and compositional variability in Figs. 2 \& 4 over a scale of several kilometers. Nonetheless, the present results are unique for this region in showing the apparent lack of a compensatory increase in picoeukaryotes to fill the declining biomass niche of photosynthetic bacteria as trophic state becomes richer. In fact, the biomass of picoeukaryotes as a group, which comprises diverse taxa and capabilities, also declines (Fig. 6). This indicates that the mechanism underlying the picoautotroph decline in richer coastal waters of the CCE is more fundamental than the unique adaptations or physical tolerances of specific taxa, like PRO and SYN. Such a general decline is consistent with the idea that the grazing pressure associated with increasing microbial loop activity ramps up as system richness increases (Landry \& Kirchman 2002, Goericke 2011a).

Fig. 8 depicts this mechanism conceptually, with increasing biomass of larger autotrophs (notably AMicro) leading to more DOC production, thereby enhancing growth and activity of H-Bact, as well as grazing losses on picophytoplankton populations (APico) that share common grazers with H-Bact. Because the grazing pressure derives indirectly from the stimulated activity of $\mathrm{H}$-Bact, this regulatory mechanism should not exhibit behaviors typical of strongly coupled predator-prey systems, such as a predator decline if picophytoplankton are temporarily, or even permanently, overgrazed (Kuipers \& Witte 2000, Goericke 2011a). 
Fig. 8. Conceptual diagram of the enhanced microbial loop hypothesis illustrating how higher grazing pressure on heterotrophic bacteria can lead to a decrease in autotrophic picophytoplankton (A-Pico) biomass in the richer system. Autotrophic size classes are A-Pico (0.2$2 \mu \mathrm{m})$, nanophytoplankton (A-Nano, 2-20 $\mu \mathrm{m})$ and microphytoplankton (A-Micro, 20-200 $\mu \mathrm{m}$ ). H-Nano: heterotrophic nanophytoplankton $(0.2-2 \mu \mathrm{m})$, DOC: dissolved organic carbon, H-Bact: heterotrophic bacteria. Circular arrows around $\mathrm{H}$ Bact represent specific growth rate. Thicker arrows and larger component boxes represent increased flows and higher standing stocks, respectively

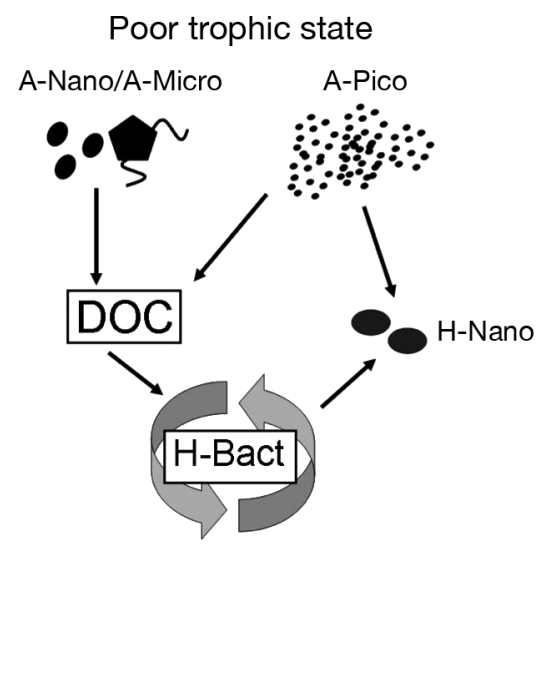

Rich trophic state

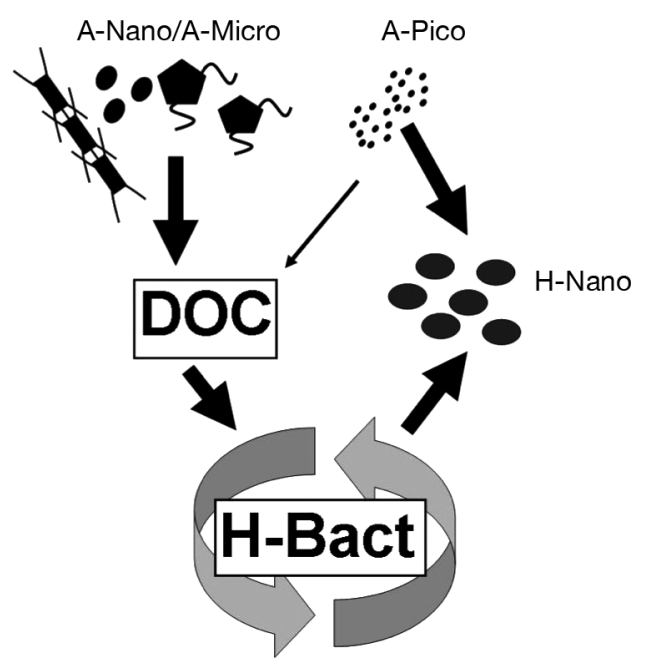

As originally defined, the microbial loop, consisting of heterotrophic prokaryotes (nominally H-Bact) and a protist-dominated grazing chain, is that part of the food web that recaptures DOC produced by food web processes (Azam et al. 1983). Activity of the microbial loop, measured as the rate of bacterial carbon production (BP), is directly influenced by primary productivity and associated processes that generate labile DOC. Thus, BP scales across trophic states with phytoplankton biomass (Cole et al. 1988, White et al. 1991). Based on the relationship BP = $2.22 \times \operatorname{chl}^{0.618}$, from Cole et al. (1988), BP would be expected to increase by 26 -fold over the range of our Tchla binned data. Since H-Bact biomass only increases by a factor of 4 over the same range of Tchla (Fig. 6), the bacterial turnover rate would necessarily be $\sim 6$ times faster in the high-chl a coastal waters than in the oligotrophic open ocean. Although we cannot speculate about how other bacterial mortality agents like viruses scale across this gradient, the 5fold biomass increase of H-Nano in our data (Fig. 6) indicates that grazing mortality may increase roughly in proportion to what is needed to account for the higher H-Bact turnover rates. Though crude, these calculations are consistent with a sharply elevated grazing impact on picophytoplankton in richer coastal waters. The enhanced microbial loop hypothesis is further supported by the high ability of biological variables (notably A-Micro and $\mathrm{H}$-Bact) to explain deviance of A-Pico biomass in GAMs for the Rich portion of our dataset ( $\mathrm{AC}>45 \mathrm{\mu g} \mathrm{C} \mathrm{l}^{-1}$; Table 5).

The present results contrast with previous studies that have sought to understand the distributions of A-Pico in the oceans principally in terms of abiotic variables. Based on an extensive compilation of flow cyto- metric measurements across major ecological provinces, Li and coworkers have advanced the idea that a few, mainly physical, variables, such as temperature, salinity, surface nitrate concentration, stratification and chl $a$, can account for most of the variability in picophytoplankton stocks (Li 2002, 2009), and that these relationships can be used to predict future states of APico in the oceans (e.g. Li et al. 2013). Over the very broad scale of the tropical to polar ecosystems sampled in these studies, it may be true that physical variables will rise to prominence as the dominant correlates of macroecological patterns. Nonetheless, these same studies also provide strong evidence that biotic variables are also important. For example, top-down (grazing) controls were invoked by Li et al. (2004) to explain why H-Bact are held below the carrying capacity set by phytoplankton biomass in productive waters, and by Li (2009) to explain why A-Pico are substantially more abundant and nanoplankton much less abundant than expected in Tracadie Bay, Prince Edward Island (Canada), an area of intensive blue mussel aquaculture (Cranford et al. 2008). In addition, while regional averages display strong linear power-law relationships between A-Pico population abundances and Tchla, the data show abundance declines at the upper end of the chlorophyll a scale (e.g. Figs. 3 \& 4 in Li 2009), as might be expected from the present results. While interpretative differences among these previous and present studies cannot be fully resolved because different systems were sampled and different variables were measured, these various studies can reasonably be seen to support the view that lower-level food web interactions can impact the biomass and composition of picoplankton along trophic gradients in ways that often cannot be predicted by abiotic variables alone. 


\section{Implication for A-Pico adaptive strategies and ecosystem modeling}

Hypothetically, A-Pico could meet the challenge of increased grazing in richer waters by growing faster, up to their maximum potential, or by adopting strategies that reduce grazing vulnerability. Examples of the latter, involving alteration of cell-surface properties or defensive chemicals, have been demonstrated for cultured isolates of PRO, SYN and other small autotrophs (e.g. Monger et al. 1999, Strom et al. 2003, 2012, Apple et al. 2011). However, the extent of their occurrence and their overall effects in natural ecosystems are presently unknown. Still, to the extent that a heightened predatory environment exists in richer marine ecosystems, one can imagine a broad array of evolved rapid growth rate versus grazing defense strategies among small phytoplankton species and ecotypes of coastal marine ecosystems. In the present study region, the diminished biomass of picophytoplankton in the richest environments (i.e. the lack of super-picos) suggests that there are physiological/ energetic limitations or trade-offs between optimal strategies for growth and grazing. This would clearly be an important and exciting topic to explore across strong coastal gradients in microbial activity with methods that are able to resolve taxon-specific differences in growth and grazing mortality rates, as well as the genetic flexibility that species or clades may have to optimize their strategic trade-offs.

Improved mechanistic understanding of predator-prey interactions at the base of the marine food web would also help to achieve more accurate representations of food web dynamics in marine ecosystem models. For instance, most models designed to investigate the interplay of bottom-up and top-down processes in shaping the size structure of plankton communities (e.g. Armstrong 1999, Poulin \& Franks 2010) ignore the microbial loop entirely or parameterize only its nutrient remineralization function. Similarly, self-assembly models of phytoplankton community composition have determined outcomes principally from the physiological capabilities of light and nutrient utilization by competing phytoplankton ecotypes (e.g. Dutkiewicz et al. 2009, 2013, Goebel et al. 2013; see also Irwin et al. 2006). Mortality, assigned as simple or fixed functions, is typically given no dynamical role in such models, even though the resource competition theory upon which the selfassembly modeling approach is based gives equal weighting to mortality and growth terms in setting the equilibrium concentrations of competing species (Tilman 1977, 1982). Here, we note that accounting for a dynamic, perhaps several-fold variability in mortality pressure on picophytoplankton that scales with total primary productivity might provide new insights or explanations for distributional patterns, especially in coastal environments, that are poorly understood or that have previously been ascribed to physiological differences. Clearly, more needs to be learned about mortality pressures and mitigating strategies of microbial populations from experimental studies in natural systems, including a definitive experimental test of the enhanced microbial loop hypothesis. At the same time, however, the sensitivities of models to reasonable scenarios of mortality dynamics should also be examined.

Acknowledgements. We thank the many colleagues who contributed to the collection and analysis of this dataset: John Wokuluk, Daniel Wick, Alexis Pasulka, Michael Stukel, Darcy Taniguchi, Mark Hodges, Daniel Lee, Lorena Linacre and Emy Daniels helped with preparation and imaging of the slide samples; Karen Selph analyzed flow cytometry samples; Shonna Dovel and Megan Roadman collected samples on CalCOFI survey cruises; and Blake Watkins collected samples on HOT cruises. We are especially thankful to Ralf Goericke for his helpful comments and thoughts while writing up this manuscript. Also, we thank the captains and crews of the numerous research vessels involved. Prof. William Li provided comments on an initial version of the paper that greatly improved the presentation. This work was funded by US National Science Foundation grants 0417616 and 1026607 (CCE-LTER Program), 0322074 (Equatorial Biocomplexity), 0324666 and 0926766 (HOT) and 0826626 (Costa Rica Dome, Flux and Zinc Experiments).

\section{LITERATURE CITED}

Agawin NSR, Duarte CM, Agustí S (2000) Nutrient and temperature control of the contribution of picoplankton to phytoplankton biomass and production. Limnol Oceanogr 45:591-600

Apple JK, Strom SL, Palenik B, Brahamsha B (2011) Variability in protists grazing and growth on different marine Synechococcus isolates. Appl Environ Microbiol 77: 3074-3084

* Armstrong RA (1999) Stable model structures for representing biogeochemical diversity and size spectra in plankton communities. J Plankton Res 21:445-464

Azam F, Fenchel T, Field JG, Grey JS, Meyer-Reil LA, Thingstad F (1983) The ecological role of water-column microbes in the sea. Mar Ecol Prog Ser 10:257-263

Barber RT, Hiscock MR (2006) A rising tide lifts all phytoplankton: growth response of other phytoplankton taxa in diatom-dominated blooms. Global Biogeochem Cycles 20:GB4S03

* Behrenfeld MJ, Falkowski PG (1997) Photosynthetic rates derived from satellite-based chlorophyll concentration. Limnol Oceanogr 42:1-20

Behrenfeld MJ, Boss E, Siegel DA, Shea DM (2005) Carbonbased ocean productivity and phytoplankton physiology from space. Global Biogeochem Cycles 19:1-14 
Binder B, Chisholm SW, Olson RJ, Frankel SL, Worden AZ (1996) Dynamics of picophytoplankton, ultraphytoplankton and bacteria in the central equatorial Pacific. DeepSea Res II 43:907-931

Brown SL, Landry MR, Yang EJ, Yoshimi MR, Bidigare RR (2008) Diatoms in the desert: plankton community response to a mesoscale eddy in the subtropical North Pacific. Deep-Sea Res II 55:1321-1333

* Calbet A, Landry MR (2004) Phytoplankton growth, microzooplankton grazing, and carbon cycling in marine systems. Limnol Oceanogr 49:51-57

Campbell L, Vaulot D (1993) Photosynthetic picoplankton community structure in the subtropical North Pacific Ocean near Hawaii (station ALOHA). Deep-Sea Res I 40: 2043-2060

Campbell L, Landry MR, Constantinou J, Nolla HA, Brown SL, Liu H, Caron DA (1998) Response of microbial community structure to environmental forcing in the Arabian Sea. Deep-Sea Res II 45:2301-2325

Chappell PD, Vedamati J, Selph KE, Cyr HA, Jenkins BD, Landry MR, Moffett JW (2016) Preferential depletion of zinc within Costa Rica upwelling dome creates conditions for zinc co-limitation of primary production. J Plankton Res 38:244-255

Chisholm SW (1992) Phytoplankton size. In: Falkowski PG, Woodhead AD (eds) Primary productivity and biogeochemical cycles in the sea. Plenum Press, New York, NY, p 213-237

Claustre H (1994) The trophic status of various oceanic provinces as revealed by phytoplankton pigment signatures. Limnol Oceanogr 39:1206-1210

* Cole JJ, Findlay S, Pace ML (1988) Bacterial production in fresh and saltwater ecosystems: a cross-system overview. Mar Ecol Prog Ser 43:1-10

* Collier JL, Palenik B (2003) Phycoerythrin-containing picoplankton in the Southern California Bight. Deep-Sea Res II 50:2405-2422

Cranford PJ, Li WKW, Strand O, Strohmeier T (2008) Phytoplankton depletion by mussel aquaculture: high resolution mapping, ecosystem modeling and potential indicators of ecological carrying capacity. ICES Ann Sci Conf 2008, Halifax, NS. ICES CM 2008/H12. www.ices.dk/ sites/pub/CM\%20Doccuments/CM-2008/H/H1208.pdf

Cullen JJ (1982) The deep chlorophyll maximum: comparing vertical profiles of chlorophyll a. Can J Fish Aquat Sci 39:791-803

* Dutkiewicz S, Follows MJ, Bragg JG (2009) Modeling the coupling of ocean ecology and biogeochemistry. Global Biogeochem Cycles 23:GB4017

* Dutkiewicz S, Scott JR, Follows MJ (2013) Winners and losers: ecological and biogeochemical changes in a warming ocean. Global Biogeochem Cycles 27:463-477

Eppley RW (1972) Temperature and phytoplankton growth in the sea. Fish Bull 70:1063-1085

Eppley RW (1992) Chlorophyll, photosynthesis and new production in the Southern California Bight. Prog Oceanogr 30:117-150

Eppley RW, Peterson BJ (1979) Particulate organic matter flux and planktonic new production in the deep ocean. Nature 282:677-680

Falkowski PG, Oliver MJ (2007) Mix and match: how climate selects phytoplankton. Nat Rev Microbiol 5:813-819

Falkowski P, Scholes RJ, Boyle E, Canadell J and others (2000) The global carbon cycle: a test of our knowledge of earth as a system. Science 290:291-296
Fenchel T (1988) Marine plankton food chains. Annu Rev Ecol Syst 19:19-38

Franck VM, Bruland KW, Hutchins DA, Brzezinski MA (2003) Iron and zinc effects on silicic acid and nitrate uptake kinetics in three high-nutrient, low-chlorophyll (HNLC) regions. Mar Ecol Prog Ser 252:15-33

*Garrison DL, Gowing MM, Hughes MP, Campbell L and others (2000) Microbial food web structure in the Arabian Sea: a US JGOFS study. Deep-Sea Res II 47:1387-1422

*Geider RJ (1987) Light and temperature dependence of the carbon to chlorophyll a ratio in microalgae and cyanobacteria: implications for physiology and growth of phytoplankton. New Phytol 106:1-34

K Goebel NA, Edwards CA, Zehr JP, Follows MJ, Morgan SG (2013) Modeled phytoplankton diversity and productivity in the California Current System. Ecol Model 264: $37-47$

Goericke R (2002) Top-down control of phytoplankton biomass and community structure in the monsoonal Arabian Sea. Limnol Oceanogr 47:1307-1323

Goericke R (2011a) The structure of marine phytoplankton communities-patterns, rules and mechanisms. Calif Coop Ocean Fish Invest Rep 52:182-197

Goericke R (2011b) The size structure of marine phytoplankton - What are the rules? Calif Coop Ocean Fish Invest Rep 52:198-204

* Gutiérrez-Rodríguez A, Slack G, Daniels EF, Selph KE, Palenik B, Landry MR (2014) Fine spatial structure of genetically distinct picocyanobacterial populations across environmental gradients in the Costa Rica Dome. Limnol Oceanogr 59:705-723

Hecky RE, Kilham P (1988) Nutrient limitation of phytoplankton in freshwater and marine environments: a review of recent evidence on the effects of enrichment. Limnol Oceanogr 33:796-822

Hirata T, Aiken J, Hardman-Mountford N, Smyth TJ, Barlow RG (2008) An absorption model to determine phytoplankton size classes from satellite ocean colour. Remote Sens Environ 112:3153-3159

* Hutchins DA, Bruland KW (1998) Iron-limited diatom growth and $\mathrm{Si}: \mathrm{N}$ uptake ratios in a coastal upwelling regime. Nature 393:561-564

* Irwin AJ, Finkel ZV, Schofield OME, Falkowski PG (2006) Scaling-up from nutrient physiology to the size-structure of phytoplankton communities. J Plankton Res 28: 459-471

Iverson RL (1990) Control of marine fish production. Limnol Oceanogr 35:1593-1604

KKarl DM, Lukas R (1996) The Hawaii Ocean Time-series (HOT) program: background, rationale and field implementation. Deep-Sea Res II 43:129-156

Kuipers BR, Witte HJ (2000) Prochlorophytes as secondary prey for heterotrophic nanoflagellates in the deep chlorophyll maximum layer of the (sub)tropical North Atlantic. Mar Ecol Prog Ser 204:53-63

Landry MR (2002) Integrating classical and microbial food web concepts: evolving views from the open-ocean tropical Pacific. Hydrobiologia 480:29-39

Landry MR (2009) Grazing processes and secondary production in the Arabian Sea: a simple food web synthesis with measurement constraints. In: Wiggert JD, Hood RR, Naqvi SWA, Brink KH, Smith SL (eds) Indian Ocean biogeochemical processes and ecological variability. American Geophysical Union, Washington, DC, p 133-146

* Landry MR, Kirchman DL (2002) Microbial community 
structure and variability in the tropical Pacific. Deep-Sea Res II 49:2669-2694

Landry MR, Ondrusek ME, Tanner SJ, Brown SL and others (2000) Biological response to iron fertilization in the eastern equatorial Pacific (IronEx II). I. Microplankton community abundances and biomass. Mar Ecol Prog Ser 201: $27-42$

Landry MR, Brown SL, Neveux J, Dupouy C, Blanchot J, Christensen S, Bidigare RR (2003) Phytoplankton growth and microzooplankton grazing in high-nutrient, lowchlorophyll waters of the equatorial Pacific: community and taxon-specific rate assessments from pigment and flow cytometric analyses. J Geophys Res 108:8142

Landry MR, De Verneil A, Goes JI, Moffett JW (2016) Plankton dynamics and biogeochemical fluxes in the Costa Rica Dome: introduction to the CRD Flux and Zinc Experiments. J Plankton Res 38:167-182

Li WKW (2002) Macroecological patterns of phytoplankton in the northwestern North Atlantic Ocean. Nature 419: $154-157$

Li WKW (2009) From cytometry to macroecology: a quarter century quest in microbial oceanography. Aquat Microb Ecol 57:239-251

Li WKW, Subba Rao DV, Harrison WG, Smith JC, Cullen JJ, Irwin B, Platt T (1983) Autotrophic picoplankton in the tropical ocean. Science 219:292-295

* Li WKW, Head EJH, Harrison WG (2004) Macroecological limits of heterotrophic bacterial abundance in the ocean. Deep-Sea Res I 51:1529-1540

Li WKW, Carmack EC, McLaughlin FA, Nelson RJ, Williams WJ (2013) Space-for-time substitution in predicting the state of picoplankton and nanoplankton in a changing Arctic Ocean. J Geophys Res Oceans 118:5750-5759

Linacre LP, Landry MR, Lara-Lara JR, Hernández-Ayón JM, Bazán-Guzmán C (2010) Picoplankton dynamics during contrasting seasonal oceanographic conditions at a coastal upwelling station off Northern Baja California, Mexico. J Plankton Res 32:539-557

Linacre L, Landry MR, Cajal-Medrano R, Lara-Lara JR and others (2012) Temporal dynamics of carbon flow through the microbial plankton community in a coastal upwelling system off northern Baja California, Mexico. Mar Ecol Prog Ser 461:31-46

Longhurst AR (1991) Role of the marine biosphere in the global carbon cycle. Limnol Oceanogr 36:1507-1526

Lynn RJ, Simpson JJ (1987) The California Current System: the seasonal variability of its physical characteristics. J Geophys Res 92:12947-12966

Marañón E (2015) Cell size as a key determinant of phytoplankton metabolism and community structure. Annu Rev Mar Sci 7:241-264

Menden-Deuer S, Lessard EJ (2000) Carbon to volume relationships for dinoflagellates, diatoms and other protist plankton. Limnol Oceanogr 45:569-579

* Mitra A, Flynn J, Burkholder JM, Berge T and others (2014) The role of mixotrophic protists in the biological carbon pump. Biogeosciences 11:995-1005

Monger BC, Landry MR (1993) Flow cytometric analysis of marine bacteria with Hoechst 33342. Appl Environ Microbiol 59:905-911

Monger BC, Landry MR, Brown SL (1999) Feeding selection of heterotrophic marine nanoflagellates based on the surface hydrophobicity of their picoplankton prey. Limnol Oceanogr 44:1917-1927

Morel A, Berthon JF (1989) Surface pigments, algal biomass profiles, and potential production of the euphotic layer: relationships reinvestigated in view of remote-sensing applications. Limnol Oceanogr 34:1545-1562

Nelson DM, Landry MR (2011) Regulation of phytoplankton production and upper-ocean biogeochemistry in the eastern equatorial Pacific: introduction to results of the Equatorial Biocomplexity project. Deep-Sea Res II 58: 277-283

Ohman MD, Barbeau KA, Franks PJS, Goericke R, Landry MR, Miller AJ (2013) Ecological transitions in a coastal upwelling ecosystem. Oceanography 26:210-219

* Pasulka AL, Landry MR, Taniguchi DAA, Taylor AG, Church MJ (2013) Temporal dynamics of phytoplankton and heterotrophic protists at Station ALOHA. Deep-Sea Res II 93:44-57

Pelaez J, McGowan JA (1986) Phytoplankton pigment patterns in the California Current as determined by satellite. Limnol Oceanogr 31:927-950

* Pérez V, Fernández E, Marañón E, Serret P, García-Soto C (2005) Seasonal and interannual variability of chlorophyll $a$ and primary production in the Equatorial Atlantic: in situ and remote sensing observations. J Plankton Res 27:189-197

Platt T (1986) Primary production of the ocean water column as a function of surface light intensity: algorithms for remote sensing. Deep-Sea Res I 33:149-163

Poulin FJ, Franks PJS (2010) Size-structured plankton ecosystems: constraints, controls and assembly instructions. J Plankton Res 32:1121-1130

Raimbault P, Rodier M, Taupier-Letage I (1988) Size fraction of phytoplankton in the Ligurian Sea and the Algerian Basin (Mediterranean Sea): size distribution versus total concentration. Mar Microb Food Webs 3:1-7

Raven JA (1986) Physiological consequences of extremely small size for autotrophic organisms in the sea. In: Platt T, Li WKW (eds) Photosynthetic picoplankton. Can Bull Fish Aquat Sci 214. Department of Fisheries and Oceans, Ottawa, ON, p 1-70

Raven JA, Finkel ZV, Irwin AR (2005) Picophytoplankton: bottom-up and top down controls on ecology and evolution. Vie Milieu 55:209-215

Ryther JH (1969) Photosynthesis and fish production in the sea. The production of organic matter and its conversion to higher forms of life vary throughout the world ocean. Science 166:72-76

Saito MA, Rocap G, Moffett JW (2005) Production of cobalt binding ligands in a Synechococcus feature at the Costa Rica upwelling dome. Limnol Oceanogr 50:279-290

Sanders RW (1991) Mixotrophic protists in marine and freshwater ecosystems. J Protozool 38:76-81

Sherr EB, Sherr BF (1993) Preservation and storage of samples for enumeration of heterotrophic protists. In: Kemp P (ed) Handbook of methods in aquatic microbial ecology. CRC Press, Boca Raton, FL, p 207-212

* Spiegelhalter DJ, Thomas A, Best NG, Lunn D (2002) Bayesian measures of model complexity and fit. J R Stat Soc B 64:583-639

Stoecker DK (1999) Mixotrophy among dinoflagellates. J Eukaryot Microbiol 46:397-401

* Strom S, Wolfe G, Slajer A, Lambert S, Clough J (2003) Chemical defense in the microplankton. II. Inhibition of protist feeding by $\beta$-dimethylsulfoniopropionate (DMSP). Limnol Oceanogr 48:230-237

* Strom SL, Brahamsha B, Fredrickson KA, Apple JK, Rodriguez AG (2012) A giant cell surface protein in 
Synechococcus WH8102 inhibits feeding by a dinoflagellate predator. Environ Microbiol 14:807-816

Stukel MR, Décima M, Selph KE, Taniguchi DAA, Landry MR (2013) The role of Synechococcus in vertical flux in the Costa Rica upwelling dome. Prog Oceanogr 112-113: 49-59

Sundt-Hansen LE, Olsen Y, Stibor H, Heldal M, Vadstein O (2006) Trophic cascades mediated by copepods, not nutrient supply rate, determine the development of picocyanobacteria. Aquat Microb Ecol 45:207-218

Taylor AG, Landry MR, Selph KE, Yang EJ (2011) Biomass, size structure and depth distributions of the microbial community in the eastern equatorial Pacific. Deep-Sea Res II 58:342-357

Taylor AG, Goericke R, Landry MR, Selph KE, Wick DA, Rodman MJ (2012) Sharp gradients in phytoplankton community structure across a frontal zone in the California Current Ecosystem. J Plankton Res 34:778-789

Taylor AG, Landry MR, Selph KE, Wokuluk JJ (2015) Temporal and spatial patterns of microbial community biomass and composition in the southern California Current Ecosystem. Deep-Sea Res II 112:117-128

Thingstad TF (1998) A theoretical approach to structuring mechanisms in the pelagic food web. Hydrobiologia 363: $59-72$

Editorial responsibility: Steven Lohrenz, New Bedford, Massachusetts, USA
Thomas AC, Strub PT (1990) Seasonal and interannual variability of pigment concentrations across a California Current frontal zone. J Geophys Res 95:13023-13042

* Tilman D (1977) Resource competition between planktonic algae: an experimental and theoretical approach. Ecology 58:338-348

Tilman D (1982) Resource competition and community structure. Monographs in Population Biology Vol 17. Princeton University Press, Princeton NJ

* Tilman D, Kilham SS, Kilham P (1982) Phytoplankton community ecology: the role of limiting nutrients. Annu Rev Ecol Syst 13:349-372

* Uitz J, Claustre H, Gentili B, Stramski D (2010) Phytoplankton class-specific primary production in the world's oceans: seasonal and interannual variability from satellite observations. Global Biogeochem Cycles 24:GB3016

* Venrick EL (2002) Floral patterns in the California Current System off southern California: 1990-1996. J Mar Res 60: 171-189

* Venrick EL (2009) Floral patterns in the California Current: the coastal-offshore boundary zone. J Mar Res 67:89-111

决White PA, Kalff J, Rasmussen JB, Gasol JM (1991) The effect of temperature and algal biomass on bacterial production and specific growth rate in freshwater and marine habitats. Microb Ecol 21:99-118

Submitted: December 4, 2017; Accepted: February 11, 2018 Proofs received from author(s): March 11, 2018 